\title{
Earmarking Tax for Indonesia's Economic Growth through the Education and Health Sector in the Long and Short Term Period
}

\author{
Faishal Fadli (Corresponding author) \\ $\mathrm{PhD}$ student, School of Economics \\ Huazhong University of Science and Technology, Wuhan, China \\ Junior Lecturer, School of Economics and Business \\ Brawijaya University, Malang Indonesia \\ Tel: 86-130-1647-9315 E-mail: faishalfadli@ub.ac.id

\begin{abstract}
Ouyang Hongbing
Professor; School of Economics

Huazhong University of Science and Technology, Wuhan, China

Tel: +8613995573589Ｅ-mail: ouyanghb@126.com
\end{abstract}

\begin{abstract}
Yaqing Liu
Associate Professor; School Medicine and Health Management

Huazhong University of Science and Technology, Wuhan, China

E-mail: anny375@126.com
\end{abstract}

Received: October 18, 2019 Accepted: November 11, 2019 Published: November 23, 2019

doi:10.5296/ber.v10i1.15889

URL: https://doi.org/10.5296/ber.v10i1.15889

\begin{abstract}
The earmarking tax policy is expected to provide quality improvements as a result of the certainty of fund allocation. There are two examples of the government undertaking an earmarking tax approach in Indonesia, where 20\% of funds are allocated for education, and 5\% of funds are allocated for health. This measure of quality improvement can be seen from the
\end{abstract}


improvement of the Human Development Index (HDI), Expected Years of Schooling (EYS), and Life Expectancy at Birth (LEB) that in turn impacts increasing economic growth (EG) during the period of earmarking tax policy in Indonesia. This research uses Path Analysis and Error Correction Model. Earmarking tax cause a negative indirect effect on EG through the education and health sector. However, in the long term, it has a positive effect on both sectors, while EYS and LEB has a negative effect. In the short term, only the health sector can increase EG.

Keywords: Earmarking tax, Human Development Index, Expected Years of Schooling, Life Expectancy at Birth, Economic Growth

\section{Introduction}

The budget allocation for the education and health sector is one of the earmarking tax policies that applied in Indonesia. 20\% is allocated for the education sector, and 5\% is allocated for the health sector, with all funds sourced from the central government budget. The basis of the application of the policy is Article 49 of Law Number 20 of 2003 Article 1 for the education sector and Law Number 9 of 2009 for the health sector. The law was created to provide a central government legal certainty. With the existence of such legal certainty, the education sector and the health sector can obtain certainty in the budget allocation of funds from the central government. Although the certainty is limited by tax compliance and tax collection, $20 \%$ of the funds allocated to the education sector and $5 \%$ of the funds allocated to the health sector will still be available regardless of the income from tax or non-tax collected.

The education and health sectors has become the primary concern of the Indonesian government as these two sectors have an essential role in economic growth (EG). Both sectors are significant contributors to human capital (Neamtu, 2015; Ogundari \& Awokuse, 2018). The general agreement amongst economists is that human capital is an essential component of a country's different growth rates (Hanushek, 2013).

The Human Development Index (HDI) can be used as a benchmark for the development of human capital. HDI is a comparison of life expectancy, literacy, education and living standards for all countries throughout the world (Albarr'an, 2018; Anand \& Sen, 2000). Based on the United Nations Development Programme (UNDP), HDI is considered a central indicator of the Human Development (HD) paradigm. The HDI is also used to classify whether a country is a developed country, a developing country, or an underdeveloped country and measures the influence of economic policy on quality of life (Davies \& Quinlivan, 2006).

Human Development Report included Indonesia in the category of Medium Human Development. In the implementation period of earmarking tax policy for the education sector (2003), HDI Indonesia marked 0.617, an increase of 0.005 from the previous period of 0.612 (2002). In the implementation period of earmarking tax policy for the health sector (2009) HDI Indonesia was 0.658. Increased 0.011 from the previous period of 0.647 (2008).

The education and health sector based on HDI also showed the same growth. Life Expectancy at Birth (LEB) as a representative of the health sector was 67.964 (2009) 
increased 0.189 from the previous year of 67.775 (2009) while Expected Years of Schooling (EYS) as a representative of the education sector marked 9.6 (2003), an increase of 0.240 from the previous year of 9.359 (2002).

Comparable to the growth of HDI, Indonesia's economy has also experienced growth. Indonesia's economic growth in 2003 was $4.78 \%$, an increase of $0.28 \%$ compared to $4.5 \%$ in 2002. In 2009, Indonesia's economic growth amounted to $4.63 \%$, having decreased by $1.38 \%$ when compared to the figure in 2008 of $6.01 \%$ (Indonesian Statistic Bureau).

Based on the data above, it can be seen that in the period of implementation of the earmarking tax policy, the education and health sectors experienced growth. Besides, economic growth has also increased. However, for more details, a more in-depth analysis is needed.

By using path analysis, this research aims to determine the direct or indirect effect of the intervening variable, in this case, of HDI while the ECM method is used to determine the long-term and short-term relationships between these variables.

The organisation of this paper is as follows: We start with a literature review and discuss earmarking tax policy. Secondly, order identifies the significant link between earmarking tax, HDI, and economic growth. Thirdly, we describe the methodology and the data, and fourthly, we discuss the main result and its interpretations. Finally, we assess the research in the conclusion.

\section{Literature Review}

\subsection{Earmarking Tax Policy}

Earmarking is a routine with regards to assigning or devoting particular revenue to the financing of particular public service. An earmarked approach is to design a policy for specific income sources of funding for public service activities that are additionally determined (Buchanan, 1963). In a more subtle sense, earmarking tax is money deliberately separated from income as a whole and can only be used for special government programs, and is used entirely for the program (Clague \& Gordon, 1940). Earmarking is intended to gradually and continuously improve the quality of service, and at the same time, create good governance and clean government (Deran, 1965; Eklund, 1972). This policy includes typically depositing tax or other revenues into an exceptional record from which the legislature appropriates money for the assigned reason. Earmarking should be possible either in the constitution or by resolution (Michael, 2015).

Earmarking isolates the budgeting procedure (Buchanan, 1963). Instead of essentially casting a yes/no ballot on a whole spending plan, earmarking makes singular votes on specific public goods. By giving the public a voice in the spending choice, earmarking helps counter the conceivable propensities of governments to develop without check, in this way expanding productivity (Bhatt, Rork, \& Walker, 2011). 


\subsection{Types of Earmarking Tax Policy}

Some experts present different opinions about the types of earmarking tax. According to one stud, earmarking tax can be divided into two forms (Bird \& Jun, 2005):

1. Substantive earmarking tax is the practice of strongly linking the source of funds to their expenses. If the funds increase, then the expenditure will also increase proportionally to the increase;

2. Symbolic earmarking tax is the practice of linking funding sources with expenditure with loose rules so that the proportion of funds spent on taxed expenditure items earmarking depends on policymakers (flexible).

There are 8 (eight) categories of Earmarking Tax, as follows:

Table 1. Earmarking Tax Categories

\begin{tabular}{|l|l|l|l|l|}
\hline Varieties of Earmarking & Expenditure & Linkage & Rationale & Example \\
\hline A & Specific & Tight & Benefit & Public enterprise \\
\hline B & Specific & Loose & Benefit & Gasoline tax and road finance \\
\hline C & Broad & Tight & Benefit & Social security \\
\hline D & Broad & Loose & Benefit & Tobacco tax and health finance \\
\hline E & Specific & Tight & None & Environmental taxes and clean-up programs \\
\hline F & Specific & Loose & None & Payroll tax and health finance \\
\hline G & Broad & Tight & None & Revenue sharing to localities \\
\hline H & Broad & Loose & None & Lottery revenues to health \\
\hline
\end{tabular}

Source: (Bird \& Jun, 2005)

Another opinion, earmarking tax is divided into two, namely full earmarking and partial earmarking (Michael, 2015). Full earmarking means that earmarking tax is the only source of financing for programs that is the government's priority, while partial earmarking means that earmarking tax is not the only financing for the program; the government can look for other funding sources to finance the government program.

Based on the types and categories described above, the earmarking tax in this research is the substantive and partial type of earmarking tax. If categorised, category $\mathrm{C}$ is included in this earmarking tax.

\subsection{The Significant Link between Earmarking Tax Policy, HDI, and Economic Growth}

Gross Domestic Product (GDP) comes from the sum of consumption, investment, government expenditure, and the difference between export and import ( $\mathrm{Y}=\mathrm{C}+\mathrm{I}+\mathrm{G}+(\mathrm{X}-\mathrm{M})$ ) (Arsyad, 2014; Keynes, 1937; Kuznets, 1966). The higher the value of these factors, the higher the value of GDP. Earmarking tax policy can change the value of government 
expenditure. However, the earmarking tax policy only allocates the amount of budget by the amount applied in the constitution (Dye, 1992). The aim of implementing the earmarking tax policy is to grow the education and health sectors (Bhatt et al., 2011). While education and health sectors are related to human resources.

There is no doubt about the significance of human resources in improving the material prosperity of society and significant developments of the economy. Three components can divide human capital: health, education, and experience/training. Its stock could increase through better education, higher health status, and new learning (Becker, 1962; Walker, 1986). Perhaps because new learning, experience, or training cannot be estimated effectively, it is the status of health and education that are utilised to measure human capital in past examinations on the connection between human capital and economic growth (Ogundari \& Awokuse, 2018). As an essential means of human capital, education and health enhance general welfare and encourages development.

The positive externalities related to human capital accumulation and the contrast among social and private education frequently cannot be solved with an "invisible hand" as they require government intervention. Several studies have proposed that government spending on education and health improve economic growth (Dissou, Didic, \& Yakautsava, 2016; Fan, Yu, \& Jitsuchon, 2008; Glomm \& Ravikumar, 1997, 1998; Sequeira \& Martins, 2008; Widodo et al., 1999).

While the advantages of government spending on education and health are broadly settled upon, there is no agreement on the fiscal instrument that is most appropriate for financing this spending. That is because in assessing financed increments in government spending on education and health influence people's utilisation sparing choices. Additionally, choices are identified with the measure of time given to the amassing of human capital. For instance, labour income tax may give a disincentive to people to collect human capital because the tax will reduce future net income (Annabi, Harvey, \& Lan, 2011; Blankenau, Simpson, Blankenau, \& Simpson, 2004; Del Rey \& Lopez-Garcia, 2013; Verbic, Majcen, \& Cok, 2009; Yeldan, 2000).

There are some recommendations from those studies regarding the most efficient fiscal instrument for increasing growth and welfare through higher public spending on education. There is a study which recommends a decrease in the personal income tax (Verbic et al., 2009). Some studies suggest an increase in the consumption tax (Blankenau et al., 2004; Yeldan, 2000). Another proposes a reallocation of public spending without changing the tax structure at all, and this is what the earmarking tax policy does (Annabi et al., 2011).

\section{Methodology and Data}

\subsection{Path Analysis}

Path analysis is a statistical analysis technique developed from multiple regression analysis (Wright, 1934). Below is a path analysis model in this research. 


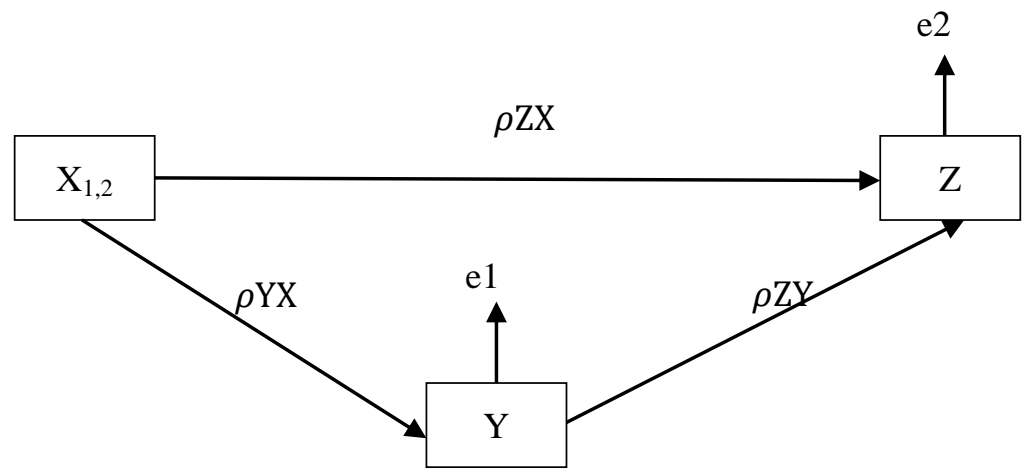

Figure 1. Path Analysis

The sub-structural equations 1 are as follows:

$$
Y=\rho Y X+\rho y e 1
$$

The sub-structural equations 2 are as follows:

$$
Z=\rho Z X+\rho Z Y+\rho Z e 2
$$

In the model above, the exogenous variable $(X)$ in the model has a direct or indirect impact (via Y) on Z (two dependent or 'endogenous' variables). In most real models, factors external to the model (including measurement errors) influence endogenous variables. The influence of the external variable is denoted by "e.", where $\mathrm{X}_{1}$ is the earmarking tax variable that uses the amount of the budget for education (EDUC), and $\mathrm{X}_{2}$ is the earmarking tax variable that uses the amount of the budget for health (HEALTH) as a variable proxy. $\mathrm{Y}$ is the variable Human Development Index (HDI). $\mathrm{Z}$ is a variable of economic growth.

\subsection{Error Correction Model}

The Error Correction Model method can be used to investigate whether there is a long-term or short-term relationship of variable HDI in the education and health sectors with economic growth (Hashimzade, Thornton, \& Davidson, 2013). The HDI variable is replaced with the variable of Expected Years of Schooling (EYS) to represent the education sector and Life Expectancy at Birth (LEB) to represent the health sector. The two substitute variables are components in the calculation of HDI.

The state of integration in the ECM model is seen in its residual stationarity. ECM requires that all variables are not stationary at the level. However, the residual / error (e) of the regression equation for those variables is stationary at the level.

ECM Implementation Stages:

1. Check that all variables are stationary. Stationary data is sequential time data that does not contain unit roots (Rothenberg \& Stock, 1997). If the mean, variance and covariance of the data are constant over time for non-stationary data, then the ECM method cannot be used (Shively \& Kohn, 1997).

2. Estimate long-term equations. The long-term equation on ECM is the usual regression equation with variables $\mathrm{y}$ and $\mathrm{x}$, which are not stationary at the level. Error (e) in this 
long-term regression equation determines whether or not there is cointegration in the $y$ and $\mathrm{x}$ variables. If $\mathrm{e}$ is stationary at the level, $\mathrm{y}$ and $\mathrm{x}$ are mutually integrated. This long-term equation is often referred to as a balanced equation and can only be used if the residual / error (e) is stationary at the level.

Long-term equation:

$$
\begin{aligned}
& \text { Education Sector: } E G_{t}=\beta_{0}+\beta_{1} E Y S_{t}+\beta_{2} E D U C_{t}+e_{t} \\
& \text { Health Sector: } E G_{t}=\beta_{0}+\beta_{1} L E B_{t}+\beta_{2} H E A L T H_{t}+e_{t}
\end{aligned}
$$

Residual:

$$
\begin{aligned}
& \text { Education Sector: } e_{t}=E G_{t}-\beta_{0}-\beta_{1} E Y S_{t}-\beta_{2} E D U C_{t} \\
& \text { Health Sector: } e_{t}=E G_{t}-\beta_{0}-\beta_{1} L E B_{t}-\beta_{2} H E A L T H_{t}
\end{aligned}
$$

EG is Economic Growth. EYS (Expected Years of Schooling) are the number of years during which a 2-year-old child can expect to spend in schooling, based on the school enrolment rates at a given date. EDUC is the amount of the budget for education. LEB (Life Expectancy at Birth) is defined as how long, on average, a newborn can expect to live, if current death rates do not change. HEALTH is the amount of the budget allocated for health.

3. Cointegration test. Check stationarity of the residual / error (e); if stationarity is at the level, the ECM is continued.

4. Estimate short-term equations. Value e (which is stationary in the long-term equation) is not used only to determine whether there is cointegration or not. Value e is also used as one of the variables in short-term equations. Short-term equations also use the same variables as the variables in the long-term equation. However, the variables are stationary, all in the same order.

Short-term equation:

$$
\begin{aligned}
& \text { Education Sector: } \triangle E G_{t}=\beta_{0}+\beta_{1} \Delta E Y S_{t}+\beta_{2} \Delta E D U C_{t}+\gamma e_{t-1}+v_{t} \\
& \text { Health Sector: } \Delta E G_{t}=\beta_{0}+\beta_{1} \Delta \mathrm{LEB} B_{t}+\beta_{2} \Delta H E A L T H_{t}+\gamma e_{t-1}+v_{t}
\end{aligned}
$$

Where $\Delta \mathrm{EG}_{\mathrm{t}}, \Delta \mathrm{EYS}_{\mathrm{t}}, \Delta \mathrm{LEB}_{\mathrm{t}}, \Delta \mathrm{EDUC}_{\mathrm{t}}$, and $\Delta \mathrm{HEALTH}_{\mathrm{t}}$ are a variable EG, EY, LEB, EDUC, and HEALTH are differentiated in the first order. Also, $\mathrm{e}_{\mathrm{t}-1}$ is a long-term residual or error equation in period $t-1 . v_{t}$ is an error of short-term equations. The coefficient $\gamma$ in the above equation (often referred to as the speed of adjustment) is the speed of the residual / error (e) in the previous period to correct the change in variable $y$ to the balance in the next period. The coefficient $\gamma$ must be significant and negative (Baltagi, Badi H., 2010).

\subsection{Data}

The data used in this research is secondary data. The type of data used is time-series data. The data is sourced from the budget allocation issued by the Indonesian government for the education and health sector, The Indonesian Human Development Index, Indonesian population life expectancy at birth, expected Indonesian years of schooling, and Indonesia's 
economic growth. All the variables are transformed into a log to follow the normal distribution. The period of data collection was linked to the implementation of earmarking tax policy. For the education sector the implementation started in 2003-2017(60 number of observations), and for the health sector the implementation started in 2009-2017(36 number of observations). Data was changed from annual data to quarterly data using the interpolation method. The interpolation method used is the Quadratic Match Sum. The result of interpolation with this method raises proportional differences in each quarter. However, if the quarterly data is added up, the result will be the same as the original data. The Quadratic Match Sum will not change the nature of the shape of the data and will assume a linear data alignment exists. Data is interpolated to increase the number $n$. This research obtained data from the Ministry of Finance, the Indonesian Statistical Center, and the United Nations Development Program.

\section{Result and Discussion}

Because we use parametric statistics, the first step is to do a normal test distribution (Gujarati, 2004). The result of calculations using the Jarque-Bera test is as follows.

Table 2. Normality Data Test

\begin{tabular}{|l|l|l|}
\hline & Jarque-Bera & Probability \\
\hline \multicolumn{2}{|l|}{ Education Sector } \\
\hline EDUC & 4,692483 & 0,095728 \\
\hline HDI & 2,807893 & 0,245626 \\
\hline EG & 4,749375 & 0,093044 \\
\hline Health Sector \\
\hline HEALTH & 3,711194 & 0,156360 \\
\hline HDI & 3,075663 & 0,214846 \\
\hline EG & 3,842006 & 0,146460 \\
\hline
\end{tabular}

All these variables are normally distributed and can be continued using path analysis concluded in these result. The path analysis can see the effect simultaneously or in combination and look at the influence partially or individually to determine the path coefficient value.

\subsection{Path Analysis}

In the first model regression output in the coefficient table, it is known that a p-value of 0.000 is less than 0.05. This result concludes that in the first model regression, the education and health variables have a significant effect on HDI variables.

Table 3. Sub-structural equations 1 output

\begin{tabular}{|l|l|l|l|l|}
\hline Variable & R Squared & $\mathrm{p}$-value & Standardized Coefficients Beta & $\varepsilon 1\left(\sqrt{\left(1-R^{2}\right)}\right.$ \\
\hline Education & 0,981 & 0,000 & 0,990 & 0,137 \\
\hline Health & 0,987 & 0,000 & 0,994 & 0,114 \\
\hline
\end{tabular}




\section{Macrothink}

Table 4. Sub-structural equations 2 output

\begin{tabular}{|l|l|l|l|l|l|}
\hline Sector & Variable & R Squared & p-value & Standardized Coefficients Beta & $\varepsilon 2\left(\sqrt{ }\left(1-R^{2}\right)\right.$ \\
\hline \multirow{2}{*}{ Education } & Educ & \multirow{2}{*}{0,273} & 0,000 & 3,724 & \multirow{2}{*}{0,852} \\
\cline { 5 - 6 } & HDI & & 0,000 & $-3,619$ & \\
\hline \multirow{2}{*}{ Health } & Health & 0,304 & 0,036 & 1,705 & \multirow{2}{*}{0,834} \\
\cline { 5 - 5 } & HDI & & 0,010 & $-2,126$ & \\
\cline { 4 - 5 } & & &
\end{tabular}

Based on the regression model output II in the table section coefficient, note that the p-value of all variables is smaller than 0.05 . These results conclude that the Education, Health and HDI variables have a significant effect on EG. Thus, the model path diagram is obtained as follows:

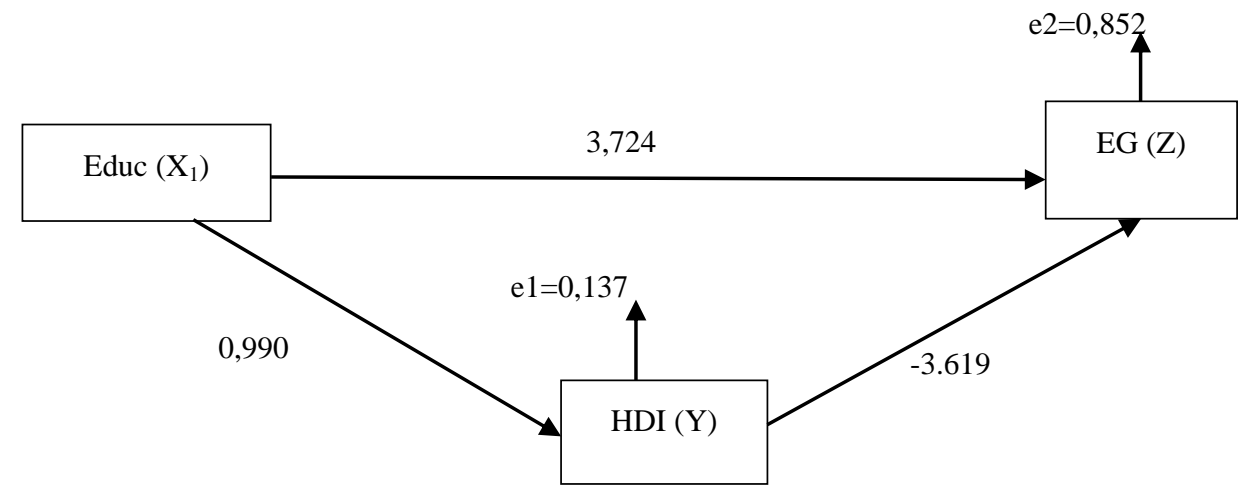

Figure 2. Education Sector path diagram

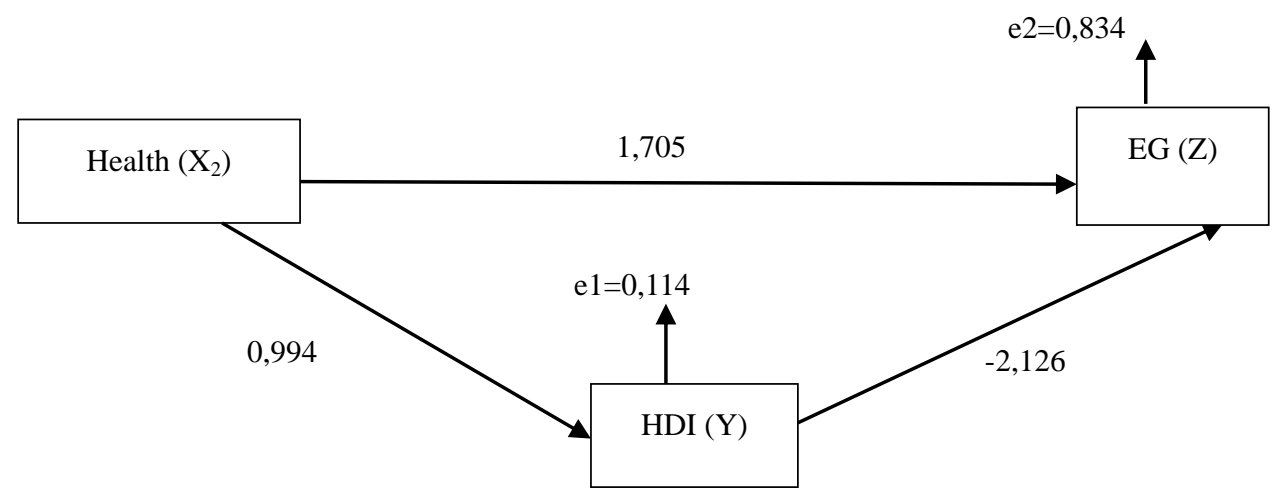

Figure 3. Health sector path diagram

The results of the research in Table 5 show a positive direct effect between variable education (0.980) and health (0.988) with the HDI. It is by the objectives in implementing the earmarking tax policy, which is to create a better growth (Clague \& Gordon, 1940). Earmarking tax policy provides certainty in budget allocations to facilitate the planning process. While success in planning is the key to growth in a better direction, the higher the budget allocation for the education and health sectors means the easier it is for both sectors to 
be able to create new, improved programs.

Based on the results in Table 5, it is clear that the earmarking tax policy has a direct positive impact on economic growth. Both sectors, education $(13,868)$ and health $(2,907)$, generate a positive direct effect. The effect of the education sector is greater than the effect of the health sector because the budget allocation by the government for the education sector is higher at $20 \%$, compared to the health sector at $5 \%$.

Table 5. The Value of Direct and Indirect Effect

\begin{tabular}{|c|c|c|}
\hline \multirow[t]{2}{*}{ Variable } & \multicolumn{2}{|l|}{ Effect } \\
\hline & Direct & Indirect \\
\hline \multicolumn{3}{|c|}{ Education Sector } \\
\hline Educ - HDI & $(\rho \mathrm{YX})^{2}=(0,990)^{2}=0,980$ & - \\
\hline \multirow[t]{3}{*}{ Educ-EG } & $(\rho Z X)^{2}=(3,724)^{2}=13,868$ & $(\rho Y X \times \rho Z Y)=0,990 \times(-3,619)=-3,582$ \\
\hline & \multicolumn{2}{|c|}{$\begin{array}{l}\text { Effect through correlative relations with HDI : } \\
\rho \mathrm{ZX} \times \quad \operatorname{rxy} \times \rho \mathrm{Zy} \quad=3,724 \times 0,990 \times \quad(-3,619)=-13,342\end{array}$} \\
\hline & \multicolumn{2}{|c|}{ Total Effect : $13,868+(-13,342)=0,525$} \\
\hline HDI - EG & $(\rho Z Y)^{2}=(-3,619)^{2}=13,097$ & - \\
\hline \multicolumn{3}{|c|}{ The effect of other variables outside of research } \\
\hline$\varepsilon 1$ & 0,137 & - \\
\hline$\varepsilon 2$ & 0,852 & - \\
\hline \multicolumn{3}{|l|}{ Health Sector } \\
\hline Health - HDI & $(\rho \mathrm{YX})^{2}=(0,994)^{2}=0,988$ & - \\
\hline \multirow[t]{3}{*}{ Health - EG } & $(\rho \mathrm{ZX})^{2}=(1,705)^{2}=2,907$ & $(\rho Y X \times \rho Z Y)=0,994 \times(-2,126)=-2,113$ \\
\hline & \multicolumn{2}{|c|}{$\begin{array}{l}\text { Effect through correlative relations with HDI : } \\
\rho \mathrm{ZX} \times \quad \text { rxy } \mathrm{x} \rho \mathrm{Zy} \quad=1,075 \times 0,994 \times \quad(-2,126)=-2,271\end{array}$} \\
\hline & \multicolumn{2}{|c|}{ Total Effect : $2,907+(-2,271)=0,635$} \\
\hline HDI - EG & $(\rho \mathrm{ZY})^{2}=(-2,126)^{2}=4,519$ & - \\
\hline \multicolumn{3}{|c|}{ The effect of other variables outside of research } \\
\hline$\varepsilon 1$ & 0,114 & - \\
\hline$\varepsilon 2$ & 0,834 & - \\
\hline
\end{tabular}

Earmarking tax policy can provide a positive effect on economic growth because earmarking tax policy reallocates public spending without addressing the tax structure at all. That is why the earmarking tax policy is the most efficient fiscal instrument for increasing growth and welfare through higher public spending on education and health (Annabi et al., 2011; Ranis, Stewart, \& Ramirez, 2000). If the budget allocation comes from an increase in taxes, it will cause a significant effect out of crowding-out, with a higher disposable income and lower savings (Blankenau et al., 2004; Del Rey \& Lopez-Garcia, 2013).

In Table 5, the education sector $(13,097)$ and the health sector $(4,519)$ show a positive direct effect on economic growth, in alignment with the theory of economic growth that states human capital can increase economic growth (Barro, 1991; Neamtu, 2015). The education 
sector has a more significant effect than the health sector because the calculation of HDI by the UNDP in the education sector has two components, namely the expected years of schooling and the average length of the school. The average length of school is the length of school (in years) that is expected to be felt by children at a certain age in the future. The health sector only has one component factor in the calculation of HDI, namely life expectancy at birth.

The surprising finding of this research is the indirect negative effect of the earmarking tax policy on economic growth through HDI. According to Table 5, both the education sector $(-13,342)$ and the health sector $(-2,271)$ produce negative effects indirectly through HDI. It can occur because government spending on the education sector and the health sector is a manifestation of government investment (Neamtu, 2015; Weil, 2014). Government investment in the education and health sectors has positive impacts on economic growth in the long run only (Dissou et al., 2016).

The implementation of the earmarking tax policy allocates $20 \%$ of the government budget for the education sector and 5\% for the health sector. As a result, a negative impact in the short run will reduce the portion of the government budget allocation for other sectors. One effect is the Indonesian government budget allocation for personnel expenditure (employee salaries). In 2017, the average salary saw a loss of 50\% to $30.8 \%$ in the first year of implementation of the policy. However, employee expenditure can positively impact short term growth of Indonesia's economy through private consumption (Kim, 2017).

The negative effect on the implementation of earmarking tax policy on economic growth through HDI in the education sector is greater than the health sector because the increase in funds leads to an increase in Gross school enrollment ratio in Indonesia. According to the UNICEF, Gross school enrollment ratio is the number of children enrolled in a level regardless of age divided by the population of the age group that officially corresponds to the same level. The following describes the Gross school enrollment ratio in Indonesia for ages 15 years above male and female between 2010-2017, as a result of the earmarking tax policy: 55,83\%; 57,69\%; 61,30\%; 63,64\%; 70,13\%; 70,32\%; 70,68\%; 71,20\% (Indonesia statistical center). As a result, the labour force absorbed by companies is reduced because children continue their education to a higher level (Wolf, 2003). The Indonesian labor force participation rate in the period of implementation of the earmarking tax policy from 2010-2015 was 69,939; 69,841; 69,729; 69,599; 69,336; 67,944 (World Bank). The decrease in the labour force is on average due to the lower-middle level workforce or labourers. Although machine can replace the position of the labourer, the development of machines is costly and takes a long period.

The reduced supply of labour companies in Indonesia also tends to increase the labour force bargaining position. It resulted in increased costs incurred by these companies. Moreover, the supply has been slowed down by the economic growth from the supply side to the company (Wolf, 2003).

Apart from that, the quality of education is more important than the quantity of education (Barro, Lee, Barro, \& Lee, 1996; Hanushek \& Kimko, 2000). While the quality of education 
in Indonesia can be said to be still low because of the unequal level of education in Indonesia, it is caused by a large number of human populations (fourth in the world) and the geographical conditions of Indonesia which is an archipelago. As a result, Indonesia's Global Talent Competitiveness Index (38.61) in 2019 is still ranked sixth in ASEAN countries (Singapore 77.27, Malaysia 58.62, Brunei Darussalam 49.9, Philippines 40.94, and Thailand 38.62). Although with the implementation of earmarking tax in 2003 the allocation funds for the education sector were the largest among the other sectors $(20 \%$ of the government budget), it still needed a long time for the quality of education to compete with developed countries. Therefore, the education sector has not been able to make a positive contribution to economic growth.

The indirect effect of the earmarking tax policy on the health sector with economic growth through HDI is smaller than the education sector due to the tradeoff between economic growth and population health (Wang, Danish, Zhang, \& Wang, 2018). High economic growth will cause a decline in the level of public health. High economic growth can improve the production process resulting in higher levels of pollution. The following shows PM2.5 air pollution micrograms / $\mathrm{m} 3$ in Indonesia during the period of implementation of the earmarking tax policy in 2010-2016: 14,488; 14.83; 14,931; 15,557; 15,222; 16,661; 16,746 (World Bank).

The earmarking tax policy for the health sector makes it easier for the health sector to design a program and implement new technology to increase the level of health of the population. For example, by introducing a regulation to control the maximum air pollution limit to 10 micrograms / $\mathrm{m} 3$ and by installing a water pollution measuring device, additional costs are required by the company to meet these standards. Also, the company can reduce its production capacity to meet these pollution standards. Consequently, this can slow economic growth.

Besides, the results of implementing earmarking tax can cause an increase in the health sector. An increase in the health sector led to an increase in life expectancy which increased the number of the human population (Cervellati, 2013). Increasing the number of human populations who have not yet entered the productive age (under the age of the labour force) or who have entered the middle age (retirement) will become a burden in the economy and it will slow the economic growth (Breyer, Costa-Font, \& Felder, 2010; Eggleston \& Fuchs, 2012). Besides, children and seniors are vulnerable to disease and thus need more intense health protection. As a result, it uses more portion of the funds allocated for the health sector.

\subsection{Error Correction Model}

The stationarity test is the first test that researchers must carry out to identify the existence of a unit's root in each variable. The stationary test in this research is conducted by the Augmented Dickey-Fuller (ADF) method. This ADF test of the significance level will be used at the error rate of $5 \%$ so that if the probability value is higher than the critical value at $\alpha$ $=5 \%$ the data is not stationary. The following table shows the data from the stationarity test results. 


\section{Ml Macrothink}

Business and Economic Research

ISSN 2162-4860

2020, Vol. 10, No. 1

To avoid the existence of a spurious correlation, three variables were tested for stationary data. Tests were carried out to achieve stationary data using integration tests. By entering the order of integration until the variable studied reaches stationary is the correct method to conduct this level of integration testing.

Table 6. Data Stationarity Results

\begin{tabular}{|c|c|c|c|c|}
\hline \multirow[t]{2}{*}{ Variable } & \multicolumn{2}{|c|}{$1^{\text {st }}$ difference } & \multicolumn{2}{|c|}{$2^{\text {nd }}$ difference } \\
\hline & Probability & Result & Probability & Result \\
\hline \multicolumn{5}{|c|}{ Education Sector } \\
\hline EDUC & 0,5600 & Non-stationary & 0,0001 & Stationary \\
\hline EG & 0,0317 & Stationary & 0,0000 & Stationary \\
\hline EYS & 0,4289 & Non-stationary & 0,0000 & Stationary \\
\hline \multicolumn{5}{|c|}{ Health Sector } \\
\hline HEALTH & 0,6826 & Non-stationary & 0,0000 & Stationary \\
\hline LEB & 0,7195 & Non-stationary & 0,0000 & Stationary \\
\hline EG & 0.1348 & Non-stationary & 0,0000 & Stationary \\
\hline
\end{tabular}

The stationarity test results show the variables meet the requirements in stage 1 . In the next stage, a regression equation will be created. EG is the dependent variable. Educ and EYS for the education sector or Health and LEB for the Health sector are independent variables. This equation is used to determine the long-term relationship between these variables.

Table 7. Long-term relationship results

\begin{tabular}{|l|l|l|l|}
\hline Variable & R-Squared & Coefficient & Prob. \\
\hline Education Sector & & \\
\hline EYS & \multirow{2}{*}{0,585543} & $-32,67545$ & 0,0000 \\
\cline { 4 - 5 } EDUC & & 5,479062 & 0,0000 \\
\hline Health Sector & \multicolumn{3}{|l}{} \\
\hline LEB & 0,272646 & $-142,2290$ & 0,0231 \\
\cline { 1 - 3 } HEALTH & & 2,676996 & 0,0862 \\
\hline
\end{tabular}

Cointegration tests are conducted to test the integration of long-term relationships between the three research variables. If it is proven that there is a cointegration relationship between the three research variables, then there is a stable long-term relationship between these variables. The cointegration test results below show these results. The cointegration test in this research used the ADF test on residual values. The results are as follows:

Table 8. Cointegration test results

\begin{tabular}{|l|l|l|l|}
\hline Sector & Coefficient & t-Statistic & Prob. \\
\hline Education & $-0,261119$ & $-3,164004$ & 0,0282 \\
\hline Health & $-0,101737$ & $-3,014767$ & 0,0449 \\
\hline
\end{tabular}


By using the ECM method, the same results are obtained with the path analysis. In the long run, earmarking tax can affect economic growth. It can be seen from the budget coefficient for education, which has a positive influence on economic growth (Educ 5.479). It takes a long time so that spending on education can have a positive impact on economic growth (Dissou et al., 2016). Making the workforce into an educated workforce takes a long time through the process of education and training. Waiting for an infant to be ready to become a workforce also takes a long time.

In the long-run, EYS variable can negatively affect economic growth because the individuals who have the labour force to pursue higher education will eventually return to the labour force. However, these individuals return with a higher level of education. The company's capacity to absorb the labour force at a more educated level is minimal, thus creating skilled unemployment (Wolf, 2003). Based on Okun's Law, an increase in the unemployment rate of $1 \%$ can reduce economic growth by $2 \%$ (Levine, 2013). It is why the EYS variable coefficient is negative and significant $(-32.67545)$ and in line with the path analysis results.

While the LEB variable can negatively affect long-term economic growth due to the increase in the human population, one per cent increase in life expectancy leads to a 1.7-2 per cent increase in population (Acemoglu \& Johnson, 2007). The increase in population can be a burden because it has not entered the productive age (Bloom, Canning, \& Fink, 2010). An increase in LEB can also result in a decrease in the amount of parental bequest given to their children which results in a decrease in physical capital accumulation (Kunze, 2014). Based on the Solow growth model, physical capital accumulation is one of the determinants of economic growth (Mankiw, Romer, \& Weil, 1992). The decrease in the amount of bequest devoted to their children also slower the private saving (Kunze, 2014). Private saving provides funds for investors to increase economic growth (Najarzadeh, Reed, \& Tasan, 2014). These results are in line with the findings of the path analysis above.

The next stage is to assess the short-term relationships of the three variables for each sector. The following are the results of the short-term analysis with the second level difference and lag two according to the results of previous calculations.

The results of the short-term analysis show compatibility with previous path analysis results. The earmarking tax policy only affects the long term for the education sector. Spending the budget for the education (EDUC) sector and Expected Year of Schooling (EYS) does not have a significant impact in the short term for economic growth. In the health sector, Life Expectancy at Birth (LEB) does not have a significant impact on economic growth in the short term. It takes a long time for the education and health sector to contribute to economic growth. These results are in line with the results of the path analysis path above. Only budget spending for the health sector (HEALTH) has a positive influence on economic growth in the short term. Because with the earmarking tax policy, budget spending for the health sector gets certainty in increasing the amount of the allocation. It can be used by the health sector to maintain society health. A healthy society can contribute directly to economic growth (Weil, 2014). 
Table 9. Short-term Analysis with the 2nd level difference results

\begin{tabular}{|l|l|l|l|}
\hline Variable & R-Squared & Coefficient & Prob. \\
\hline Education Sector \\
\hline EYS & \multirow{2}{*}{0,140830} & 4,441259 & 0,8282 \\
\cline { 4 - 5 } & & 2,263022 & 0,0682 \\
\cline { 4 - 5 } EDUC & $-0,124189$ & 0,0102 \\
\hline Res & \multirow{3}{|l}{} \\
\hline Health Sector & 0,458824 & 724,2549 & 0,2346 \\
\hline LEB & 14,57191 & 0,0002 \\
\hline HEALTH & & $-0,088459$ & 0,0311 \\
\hline Res & &
\end{tabular}

\subsection{Linearity Test}

This linearity test is not necessarily done by researchers because the purpose of this test depends on the purpose of the linear regression test. If the purpose is to form a new and Best Linear Unbiased Estimation (BLUE) model, then this test must be done (Gujarati, 2004). The linearity test in this research was done using the Ramsey Reset Test. The test results can be seen in the value of the p-value shown in the probability column F-statistics. The results in this study were 0,2889 for the education sector and 0,4689 for the health sector which are > 0,05 . Thus, it can be concluded that the independent variables are linear with the dependent variable.

Table 10. Ramsey RESET Test

\begin{tabular}{|l|l|l|l|}
\hline & Value & Df & Probability \\
\hline Education Sector \\
\hline t-statistic & 1,078531 & 32 & 0,2889 \\
\hline F-statistic & 1,163229 & $(1,32)$ & 0,2889 \\
\hline Likelihood ratio & 1,730077 & 1 & 0,2569 \\
\hline Health Sector \\
\hline t-statistic & 0,729665 & 56 & 0,4686 \\
\hline F-statistic & 0,532412 & $(1,56)$ & 0,4686 \\
\hline Likelihood ratio & & 1 & 0,4512 \\
\hline
\end{tabular}

\subsection{Heteroscedasticity Test}

The Heteroscedasticity test is a test that assesses whether there is an inequality of variance from the residual for all observations in the linear regression model (Greene, 2012). This test is one of the standard assumption tests that must be done in linear regression. If heteroscedasticity assumptions are not fulfilled, then the regression model is declared invalid as a forecasting tool. This research uses the Breusch Pagan Godfrey test, along with the results: 
Table 11. Breusch Pagan Godfrey Test Results

\begin{tabular}{|l|l|l|}
\hline & Education Sector & Health Sector \\
\hline F-statistic & & \\
\hline Obs*R-Squared & 1,448473 & 1,185538 \\
\hline Scaled explained SS & 2,901930 & 2,415763 \\
\hline Probability & 2,728264 & 1,069612 \\
\hline Prob. Chi-Square(2) & 0,2434 & 0,3191 \\
\hline Prob. Chi-Square(2) & 0,2343 & 0,2988 \\
\hline Prob. Chi-Square(2) & 0,2556 & 0,5858 \\
\hline
\end{tabular}

The p-value is indicated by the value of the Probability, which is equal to 2,728264 for the education sector and 1,069612 for the health sector which are >0,05. It means that the regression model shows homoscedasticity, or in other words, there is no problem with the assumption of non-heteroscedasticity.

\subsection{Multicollinearity Test}

Multicollinearity tests assess whether there is a correlation or intercorrelation between independent variables in the regression model (Baltagi, Badi H., 2010). The multicollinearity test in this study used Variance Inflation Factors (VIF). The results are as follow:

Table 12. VIF Results

\begin{tabular}{|l|l|l|l|}
\hline Variable & Centered VIF & Uncentered VIF & Coefficient Variance \\
\hline Education Sector \\
\hline EDUC & 1,049204 & 1,187400 & 12,30544 \\
\hline EYS & 1,002039 & 1,179424 & 356484,9 \\
\hline Health Sector \\
\hline HEALTH & 1,187116 & 1,050006 & 1,049204 \\
\hline LEB & 1,170558 & 1,008785 & 1,002039 \\
\hline
\end{tabular}

The results of the multicollinearity test above indicate that the Centered VIF value for all variables are below 10 . Then it can be stated that there is no multicollinearity problem in the prediction model.

\subsection{Normality Test}

The Normality Test is a test carried out to assess the distribution of data in a group of data or variables where it is normally distributed or not (Greene, 2012). The assumption of normality in OLS linear regression is based on the residual, not the variable. Based on the practical experience of some statisticians, data with more than 30 digits $(n>30)$ can already be assumed to be normally distributed (Gujarati, 2004). The results are as follow: 
Table 13. Normality Test

\begin{tabular}{|l|l|l|}
\hline & Jarque-Bera & Probability \\
\hline Education Sector & 0,970370 & 0,615583 \\
\hline Health Sector & 1,500248 & 0,472308 \\
\hline
\end{tabular}

The normality test in this study used the Jarque-Bera Test. All of the significant values of the test are $<0.05$. It results in acceptance of $\mathrm{H} 0$ which means the residual is normally distributed.

\subsection{Autocorrelation Test}

Autocorrelation Test is a statistical analysis performed to find out whether there are variable correlations in the prediction model with changes in time (Enders, 2004). Therefore, if the assumption of autocorrelation occurs in a prediction model, then the disturbance value no longer pairs freely, but pairs in autocorrelation. An autocorrelation test in a linear regression model must be done if the data are time-series data or sequential time.

The Durbin-Watson Stat value in the model in this study are 2,307903 for the education sector and 2,383645 for the health sector. This value are the value of the Durbin Watson (DW) Calculate. The value are compared with the $\mathrm{DL}=1,54853$ and $\mathrm{DU}=1,61617$ (education sector) and $\mathrm{DL}=1,41065$ and DU=1.52451 (health sector) values in the Durbin Watson table. The results are DW> DU and value (4-DW)> DU, indicating there is no autocorrelation problem, in terms of both positive and negative autocorrelation.

Another autocorrelation test is a serial correlation. This research uses the Breusch-Godfrey Serial Correlation LM Test method. The value of Prob Chi-Square (2) is the value of the Breusch-Godfrey Serial Correlation LM test value, which are equal to 0,3819 for the education sector and 0,2776 for health sector where > 0.05, meaning that H0 accepted; in other words, there is no problem with serial autocorrelation.

\section{Conclusion}

The earmarking tax policy in the education sector and the health sector can bring direct positive effects on economic growth. However, the earmarking tax policy also brings negative indirect effects on economic growth in both sectors through the HDI variable. For the education sector, it is caused by the reduced supply of labour companies in Indonesia also tends to increase the labour force bargaining position and the quality of education in Indonesia is still low. For the health sector, it is caused by enforcement of regulations on air pollution can slowing down the level of production and increase production costs. Besides, an increase in the health sector can increase Life Expectancy thereby increasing the human population that can burden the economy. To further explain the effect of each sector, more specifically, using Expected Years of Schooling (EYS) variables represents the education sector and Life Expectancy at Birth (LEB) represents the health sector. A negative relationship with economic growth occurs in the long run for EYS and LEB variables. It is because an increase in EYS can reduce the workforce. Whereas an increase in LEB can decrease the amount of parental bequest given to their children which results in a decrease in 
physical capital accumulation. The budget for spending on the education sector gives positive relations to economic growth occurs on long terms. Because it takes a long time for the health sector to have an impact on economic growth. However, in the short term budget for spending on the health sector give positive relations to economic growth. The availability of excellent health services for the community can improve public health resulting in increased productivity.

The recommendations from the results of the research are to provide advice that the budget issued by the state using the Earmarking Tax Policy must be competent in each sector. The Ministry of Education must be able to allocate a budget to develop human resources that can be absorbed directly by the company, for example, the development of vocational schools. For the health sector, the budget allocation from the earmarking tax policy can be used for research and development to develop waste processing technology for environmental reasons. These budget allocations can create sustainable economic growth.

Economic growth is not only influenced by Human Capital. The earmarking tax policy also can not only affect Human Capital. It is a limitation of this research. Further research can be developed to assess the Earmarking Tax Policy Effect on economic growth by using other variables and case studies of other countries.

\section{Conflict of interest}

The authors declare no potential conflict of interest.

\section{Acknowledgement}

Financial support from the MOE (Ministry of Education in China) Project of Humanities and Social Sciences (Grant No. 19YJA790067) is gratefully acknowledged.

\section{References}

Acemoglu, D., \& Johnson, S. (2007). Disease and development: The effect of life expectancy on economic growth. Journal of Political Economy. https://doi.org/10.1086/529000

Albarr'an, D. G. (2018). Health and economic development since 1900. Economics and Human Biology, 31(september 2018), 228-237. [Online] Available:

https://doi.org/10.1016/j.ehb.2018.08.009

Anand, S., \& Sen, A. (2000). Human development and economic sustainability. World Development. https://doi.org/10.1016/S0305-750X(00)00071-1

Annabi, N., Harvey, S., \& Lan, Y. (2011). Public expenditures on education, human capital and growth in Canada: An OLG model analysis. Journal of Policy Modeling, 33(6), 852-865. https://doi.org/10.1016/j.jpolmod.2011.08.020

Arsyad, L. (2014). Concept and Measurement of Economic Development. Development economics module.

Baltagi, Badi H. (2010). econometrics solutions manual, 2nd ed. Analysis. https://doi.org/10.1007/978-3-642-03383-4 


\section{Macrothink

Barro, R. J. (1991). Economic Growth in a Cross Section of Countries. The Quarterly Journal of Economics. https://doi.org/10.2307/2937943

Barro, R. J., Lee, J.-W., Barro, R., \& Lee, J.-W. (1996). International Measures of Schooling Years and Schooling Quality. American Economic Review, 86(2), 218-223.

Becker, G. S. (1962). Investment in Human Capital: A Theoretical Analysis. Journal of Political Economy. https://doi.org/10.1086/258724

Bhatt, R., Rork, J. C., \& Walker, M. B. (2011). Earmarking and the business cycle: The case of state spending on higher education. Regional Science and Urban Economics, 41(4), 352-359. https://doi.org/10.1016/j.regsciurbeco.2011.01.008

Bird, R. M., \& Jun, J. (2005). Earmarking in Theory and Korean Practice. International Studies Program Working Paper Series.

Blankenau, W., Simpson, N. B., Blankenau, W., \& Simpson, N. (2004). Journal of development economics. Journal of Development Economics (Vol. 73). [North-Holland Pub. Co.]. [Online] Available:

https://econpapers.repec.org/article/eeedeveco/v_3a73_3ay_3a2004_3ai_3a2_3ap_3a583-605 .htm

Bloom, D. E., Canning, D., \& Fink, G. (2010). Implications of population ageing for economic growth. Oxford Review of Economic Policy. https://doi.org/10.1093/oxrep/grq038

Breyer, F., Costa-Font, J., \& Felder, S. (2010). Ageing, health, and health care. Oxford Review of Economic Policy, 26(4), 674-690. https://doi.org/10.1093/oxrep/grq032

Buchanan, J. (1963). The Economics of Earmarked Taxes. Journal of Political Economy. https://doi.org/10.1086/258794

Cervellati, M. (2013). The Economic and Demographic Transition, Mortality, and Comparative Development.

Clague, E., \& Gordon, J. (1940). Earmarking tax funds for welfare purposes.

Davies, A., \& Quinlivan, G. (2006). A panel data analysis of the impact of trade on human development. The Journal of Socio-Economics, 35(5), 868-876.

https://doi.org/10.1016/J.SOCEC.2005.11.048

Del Rey, E., \& Lopez-Garcia, M.-A. (2013). Endogenous growth, education subsidies, and intergenerational transfers, (July).

Deran, E. (1965). EARMARKING AND EXPENDITURES: A SURVEY AND A NEW TEST. National Tax Journal.

Dissou, Y., Didic, S., \& Yakautsava, T. (2016). Government spending on education, human capital accumulation, and growth. Economic Modelling.

https://doi.org/10.1016/j.econmod.2016.04.015

Dye, R. F. (1992). COMPOSITION OF EXPENDITURES, 20(4), 543-556. 


\section{Macrothink

Eggleston, K. N., \& Fuchs, V. R. (2012). The new demographic transition: Most gains in life expectancy now realized late in life. Journal of Economic Perspectives, 26(3), 137-156. https://doi.org/10.1257/jep.26.3.137

Eklund, P. (1972). A Theory of Earmarking Appraised. National Tax Journal.

Enders, W. (2004). Applied econometric time series (Second). J. Wiley.

Fan, S., Yu, B., \& Jitsuchon, S. (2008). Does Allocation of Public Spending Matter in Poverty Reduction? Evidence from Thailand*. Asian Economic Journal, 22(4), 411-430.

https://doi.org/10.1111/j.1467-8381.2008.00284.x

Glomm, G., \& Ravikumar, B. (1997). Productive government expenditures and long-run growth. Journal of Economic Dynamics and Control.

https://doi.org/10.1016/0165-1889(95)00929-9

Glomm, G., \& Ravikumar, B. (1998). Flat-Rate Taxes, Government Spending on Education, and Growth. Review of Economic Dynamics. https://doi.org/10.1006/redy.1997.0001

Greene, W. H. (2012). Econometric Analysis (Seventh Edition). Prentice Hall.

Gujarati, D. N. (2004). Basic Econometric. The McGraw-Hill.

https://doi.org/10.1126/science.1186874

Hanushek, E. A. (2013). Economic growth in developing countries: The role of human capital. Economics of Education Review. https://doi.org/10.1016/j.econedurev.2013.04.005

Hanushek, E. A., \& Kimko, D. D. (2000). Schooling, Labor-Force Quality, and the Growth of Nations. American Economic Review, 90(5), 1184-1208.

https://doi.org/10.1257/aer.90.5.1184

Hashimzade, N., Thornton, M., \& Davidson, J. (2013). Cointegration and error correction. In Handbook of Research Methods and Applications in Empirical Macroeconomics. https://doi.org/10.4337/9780857931023.00013

Keynes, J. M. (1937). The General Theory of Employment. The Quarterly Journal of Economics. https://doi.org/10.2307/1882087

Kim, H. (2017). The Effect of Consumption on Economic Growth in Asia. https://doi.org/10.4172/2375-4389.1000259

Kunze, L. (2014). Life expectancy and economic growth. Journal of Macroeconomics. https://doi.org/10.1016/j.jmacro.2013.12.004

Kuznets, S. (1966). Modern economic growth; rate, structure, and spread. Modern economic growth; rate, structure, and spread. https://doi.org/10.1016/0012-365X(94)90268-2

Levine, L. (2013). Economic Growth and the Unemployment Rate. Congressional Research Services, 75-5700/R4, 1-10. https://doi.org/R42063

Mankiw, N. G., Romer, D., \& Weil, D. N. (1992). A Contribution to the Empirics of 
Economic Growth. The Quarterly Journal of Economics. https://doi.org/10.2307/2118477

Michael, J. (2015). Earmarking State Tax Revenues, 3529, 92-94. [Online] Available:

http://www.house.leg.state.mn.us/hrd/pubs/earmarking.pdf

Najarzadeh, R., Reed, M., \& Tasan, M. (2014). Relationship between Savings and Economic Growth: The Case For Iran. Journal of International Business and Economics, 2(4), 2374-2194. https://doi.org/10.15640/jibe.v2n4a7

Neamtu, D. M. (2015). Education, the Economic Development Pillar. Procedia - Social and Behavioral Sciences, 180(November 2014), 413-420.

https://doi.org/10.1016/j.sbspro.2015.02.138

Ogundari, K., \& Awokuse, T. (2018). Human capital contribution to economic growth in Sub-Saharan Africa: Does health status matter more than education? Economic Analysis and Policy. https://doi.org/10.1016/j.eap.2018.02.001

Ranis, G., Stewart, F., \& Ramirez, A. (2000). Economic growth and human development. World Development. https://doi.org/10.1016/S0305-750X(99)00131-X

Rothenberg, T. J., \& Stock, J. H. (1997). Inference in a nearly integrated autoregressive model with nonnormal innovations. Journal of Econometrics.

https://doi.org/10.1016/S0304-4076(97)00040-7

Sequeira, T. N., \& Martins, E. V. (2008). Education public financing and economic growth: an endogenous growth model versus evidence. Empirical Economics, 35(2), 361-377. https://doi.org/10.1007/s00181-007-0162-1

Shively, T. S., \& Kohn, R. (1997). A Bayesian approach to model selection in stochastic coefficient regression models and structural time series models. Journal of Econometrics. https://doi.org/10.1016/0304-4076(95)01781-X

Verbic, M., Majcen, B., \& Cok, M. (2009). Education and Economic Growth in Slovenia: A Dynamic General Equilibrium Approach with Endogenous Growth. [Online] Available: https://mpra.ub.uni-muenchen.de/17817/

Walker, B. W. (1986). Investment in human capital in Africa. The Environmentalist. https://doi.org/10.1016/0379-6787(90)90024-Y

Wang, Z., Danish, Zhang, B., \& Wang, B. (2018). Renewable energy consumption, economic growth and human development index in Pakistan: Evidence form simultaneous equation model. Journal of Cleaner Production (Vol. 184). Elsevier Ltd.

https://doi.org/10.1016/j.jclepro.2018.02.260

Weil, D. N. (2014). Health and Economic Growth. Handbook of Economic Growth. https://doi.org/10.1016/B978-0-444-53540-5.00003-3

Widodo, A., Waridin, Maria K., J., Seetanah, B., Rammesur, S., Rojid, S., ... Griliches, Z. (1999). Government Spending, growth and poverty: an analysis of interlinkages in Rural India. Frontier of Development Economist (The Future in Perpective). 
https://doi.org/10.1016/S1573-4412(83)01007-7

Wolf, A. (2003). Education and growth. New Economy.

https://doi.org/10.1111/1468-0041.00282

Wright, S. (1934). The Method of Path Coefficients. The Annals of Mathematical Statistics, 5(3), 161-215. https://doi.org/10.1214/aoms/1177732676

Yeldan, E. (2000). Financing of Public Education In a Debt Constrained Economy: Investigation of Fiscal Alternatives In An OLG Model of Endogenous Growth for Turkey. [Online] Available:

http://www.academia.edu/23881271/Financing_of_Public_Education_In_a_Debt_Constraine d_Economy_Investigation_of_Fiscal_Alternatives_In_An_OLG_Model_of_Endogenous_Gr owth_for_Turkey

\section{Appendix}

Data

\begin{tabular}{|c|c|c|c|c|c|c|}
\hline Year & $20 \%$ Education & $5 \%$ Health & HDI & EG & LEB & EYS \\
\hline 2000Q1 & 9.671628528 & 8.978481354 & 4.17524 & 5.9025 & 66.1485 & 8.69725 \\
\hline $2000 \mathrm{Q} 2$ & 9.786552895 & 9.09340572 & 4.177911 & 5.575 & 66.194 & 8.7575 \\
\hline 2000Q3 & 9.901477263 & 9.208330087 & 4.180581 & 5.2475 & 66.2395 & 8.81775 \\
\hline 2000Q4 & 10.01640163 & 9.323254453 & 4.183252 & 4.92 & 66.285 & 8.878 \\
\hline 2001Q1 & 10.131326 & 9.43817882 & 4.185923 & 4.5925 & 66.3305 & 8.93825 \\
\hline 2001Q2 & 10.24625037 & 9.553103186 & 4.188594 & 4.265 & 66.376 & 8.9985 \\
\hline 2001Q3 & 10.36117473 & 9.668027553 & 4.191265 & 3.9375 & 66.4215 & 9.05875 \\
\hline 2001Q4 & 10.4760991 & 9.782951919 & 4.193936 & 3.61 & 66.467 & 9.119 \\
\hline 2002Q1 & 10.46969093 & 9.776543744 & 4.192107 & 3.8325 & 66.511 & 9.179 \\
\hline $2002 \mathrm{Q} 2$ & 10.46328275 & 9.770135569 & 4.190278 & 4.055 & 66.555 & 9.239 \\
\hline 2002Q3 & 10.45687458 & 9.763727395 & 4.188449 & 4.2775 & 66.599 & 9.299 \\
\hline 2002Q4 & 10.4504664 & 9.75731922 & 4.18662 & 4.5 & 66.643 & 9.359 \\
\hline 2003Q1 & 10.47236801 & 9.779220826 & 4.19589 & 4.57 & 66.68725 & 9.41925 \\
\hline 2003Q2 & 10.49426961 & 9.801122431 & 4.20516 & 4.64 & 66.7315 & 9.4795 \\
\hline 2003Q3 & 10.51617122 & 9.823024037 & 4.21443 & 4.71 & 66.77575 & 9.53975 \\
\hline 2003Q4 & 10.53807282 & 9.844925642 & 4.223701 & 4.78 & 66.82 & 9.6 \\
\hline 2004Q1 & 10.56917551 & 9.876028328 & 4.225213 & 4.8425 & 66.8655 & 9.66025 \\
\hline 2004Q2 & 10.600 & 014 & 25 & 4.905 & & \\
\hline 2004Q3 & 10.63138088 & 9.938233701 & 4.228237 & 4.9675 & 66.9565 & 9.78075 \\
\hline 2004Q4 & 10.66248357 & 9.969336387 & 4.229749 & 5.03 & 67.002 & 9.841 \\
\hline 2005Q1 & 10.73239258 & 10.03924539 & 4.232895 & 5.195 & 67.04925 & 9.901 \\
\hline 2005Q2 & 10.80230158 & 10.1091544 & 4.236041 & 5.36 & 67.0965 & 9.961 \\
\hline 2005Q3 & 10.87221059 & 10.1790634 & 4.239187 & 5.525 & 67.14375 & 10.021 \\
\hline 2005Q4 & 10.94211959 & 10.24897241 & 4.242333 & 5.69 & 67.191 & 10.081 \\
\hline 2006Q1 & 10.99533038 & 10.3021832 & 4.244231 & 5.6425 & 67.23975 & 10.14125 \\
\hline 2006Q2 & 11.04854117 & 10.35539399 & 4.246128 & 5.595 & 67.2885 & 10.2015 \\
\hline 2006Q3 & 11.10175196 & 10.40860478 & 4.248025 & 5.5475 & 67.33725 & 10.26175 \\
\hline 2006Q4 & 11.15496275 & 10.46181557 & 4.249923 & 5.5 & 67.386 & 10.322 \\
\hline 2007Q1 & 11.17332272 & 10.48017554 & 4.251664 & 5.7125 & 67.43475 & 10.38225 \\
\hline 2007Q2 & 11.1916827 & 10.49853552 & 4.253406 & 5.925 & 67.4835 & 10.4425 \\
\hline 2007Q3 & 11.21004267 & 10.51689549 & 4.255147 & 6.1375 & 67.53225 & 10.50275 \\
\hline
\end{tabular}




\begin{tabular}{|c|c|c|c|c|c|c|}
\hline 2007Q4 & 1.22840264 & 10.53525546 & 4.256888 & 6.35 & 67.581 & 10.563 \\
\hline 2008Q1 & 11.2968929 & 10.60374572 & 4.258934 & 6.265 & 67.6295 & 10.62325 \\
\hline 2008Q2 & 11.36538317 & 10.67223599 & 4.26098 & 6.18 & 7.678 & 10.6835 \\
\hline 2008Q3 & 11.43387343 & 10.74072625 & 4.263026 & 6.095 & 7.7265 & 0.74375 \\
\hline 2008Q4 & 11.50236369 & 10.80921651 & 4.265071 & 6.01 & 67.775 & 10.804 \\
\hline 2009Q1 & 11.50521503 & 10.81206785 & 4.267135 & 5.665 & 67.82225 & 10.864 \\
\hline 2009Q2 & 11.50806636 & 10.81491918 & 4.269199 & 5.32 & 67.8695 & 10.924 \\
\hline 2009Q3 & 11.5109177 & 10.81777052 & 4.271263 & 4.975 & 67.91675 & 10.984 \\
\hline 2009Q4 & 11.51376903 & 10.82062185 & 4.273327 & 4.63 & 67.964 & 11.044 \\
\hline 2010Q1 & 11.54325854 & 11136 & 4.275098 & 5.0275 & 68.0105 & 11.1055 \\
\hline 2010Q2 & 11.57274804 & 10.87960086 & 4.276868 & 5.425 & 68.057 & 11.167 \\
\hline 2010Q3 & 11.60 & 10.9 & 4.278639 & 5.8 & 68. & 1.2285 \\
\hline 2010Q4 & 11.63 & 10.9 & 4.280409 & 6.22 & 68. & 20 \\
\hline 2011Q1 & 84 & & 4.28 & & & 11 \\
\hline 2011Q2 & 1 & & 4.287669 & $63=$ & & \\
\hline 201 & & & & & & \\
\hline 201 & & & & & & \\
\hline 201 & & & & & & \\
\hline 201 & & & 4.2 & & & \\
\hline 201 & & & & & & \\
\hline 201 & & & & 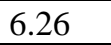 & & \\
\hline 201 & & & & & & \\
\hline 201 & & & & & & \\
\hline 201 & & & & - & & 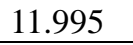 \\
\hline 201 & & & & 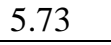 & & \\
\hline 201 & & & & 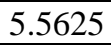 & & \\
\hline 201 & & & & & - & \\
\hline 201 & & & 4.32 & 5.2275 & & \\
\hline 2014Q4 & & & 4.32 & 3 & -1 & 39 \\
\hline 2015Q1 & & 13 & 4.325663 & $\mathrm{~J}$ & 8. & 12.43 \\
\hline 2015Q2 & 1 & & 4.327986 & 4.97 & 68. & 12.47 \\
\hline 2015Q3 & 12 & 288 & 4.33031 & 4.925 & 68.98275 & 12.51 \\
\hline 2015Q4 & 1 & 875 & 4.332633 & 4.8 & 69.0 & 12.55 \\
\hline 2016Q1 & 1 & 1729 & 4.334935 & 4.9175 & 69.0665 & 12.5925 \\
\hline 2016Q2 & 12.2 & 583 & 4.337237 & 4.955 & 69.108 & 12.635 \\
\hline 2016Q3 & 12.2 & 37 & 4.339539 & 4.9925 & 69.1495 & 12.6775 \\
\hline 2016Q4 & 12.2 & 291 & 4.341841 & 5.03 & 69.191 & 12.72 \\
\hline 2017Q1 & & 295 & 4.344122 & 5.0 & 69.2465 & 12752 \\
\hline 2017Q2 & & 298 & 4.346403 & 5.05 & 69.302 & 12.785 \\
\hline 201 & & & 4.3 & 5.0 & 69.3575 & 12.8175 \\
\hline 2017 & 12.24551 & 11.55236305 & 4.350965 & $5.0^{\prime}$ & 69.413 & 1285 \\
\hline
\end{tabular}




\section{Macrothink}

Business and Economic Research ISSN 2162-4860 2020, Vol. 10, No. 1

\section{Appendix}

Normality Test

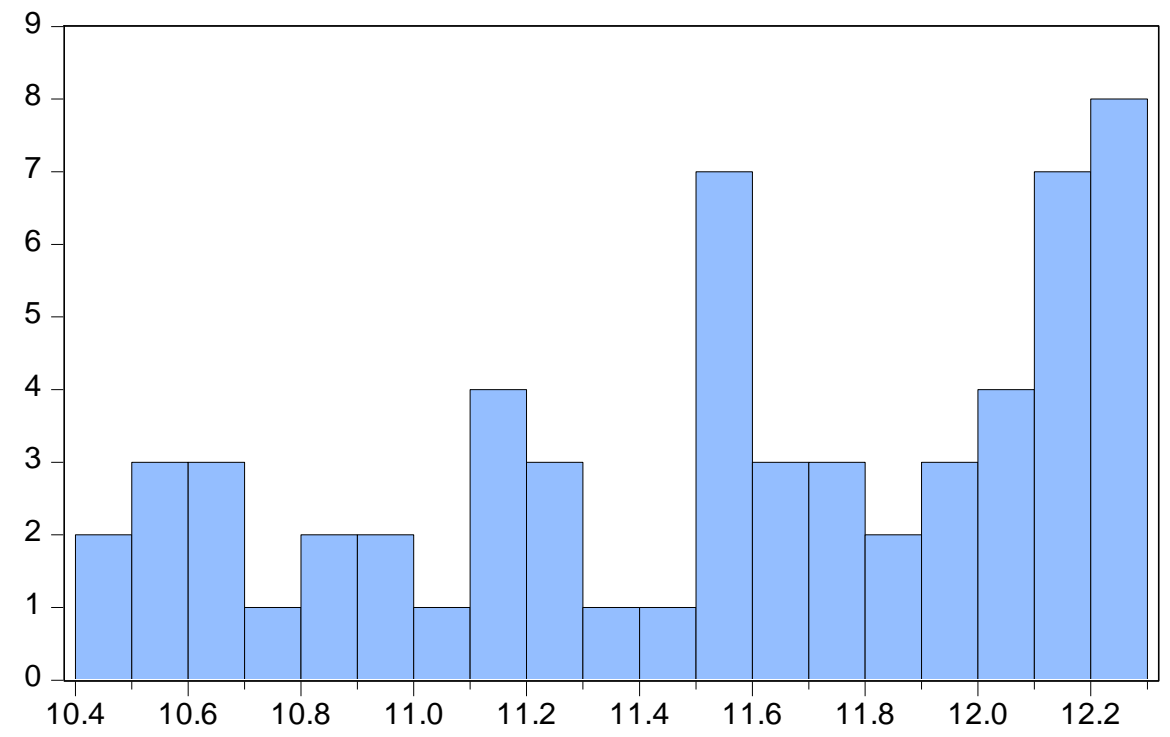

Series: EDUC

Sample 2003Q1 2017Q4

Observations 60

Mean

11.54225

Median

11.58749

Maximum

12.24671

Minimum $\quad 10.47237$

Std. Dev. $\quad 0.575785$

Skewness $\quad-0.414141$

Kurtosis $\quad 1.908697$

Jarque-Bera

4.692483

Probability

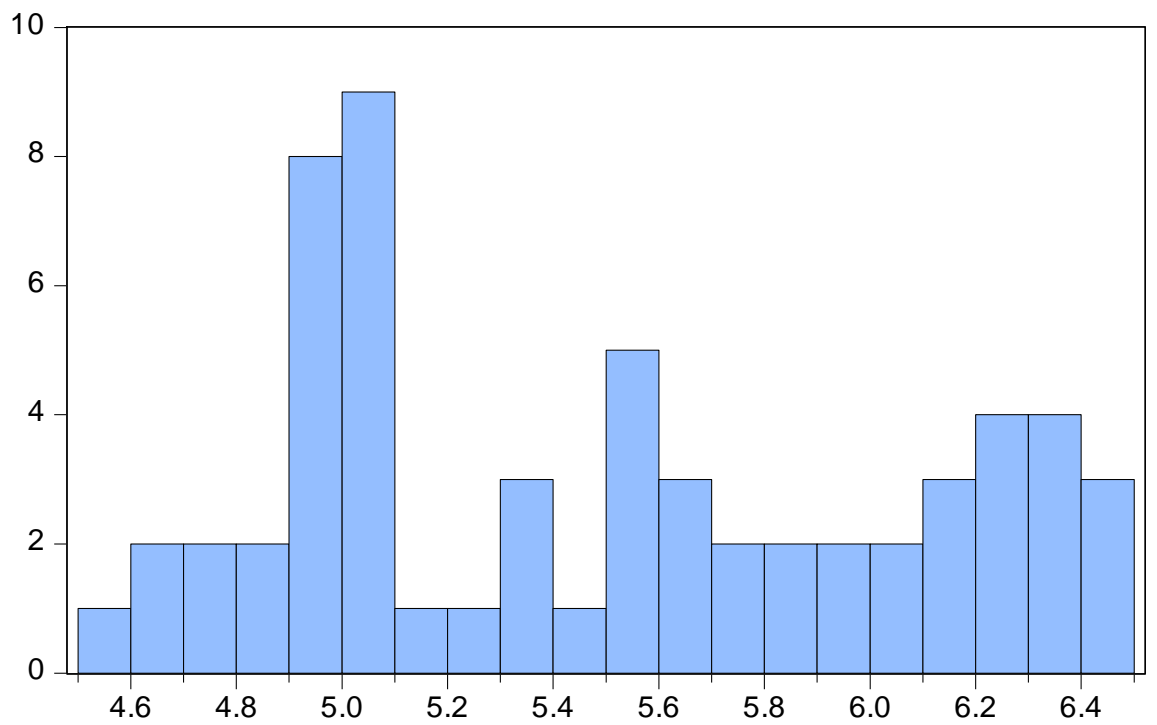

Series: EG

Sample 2003Q1 2017Q4

Observations 60

Mean

5.501083

Median

5.462500

Maximum

6.490000

Minimum

4.570000

Std. Dev.

0.574697

Skewness

0.219657

Kurtosis

1.693572

Jarque-Bera

4.749375

Probability

0.093044




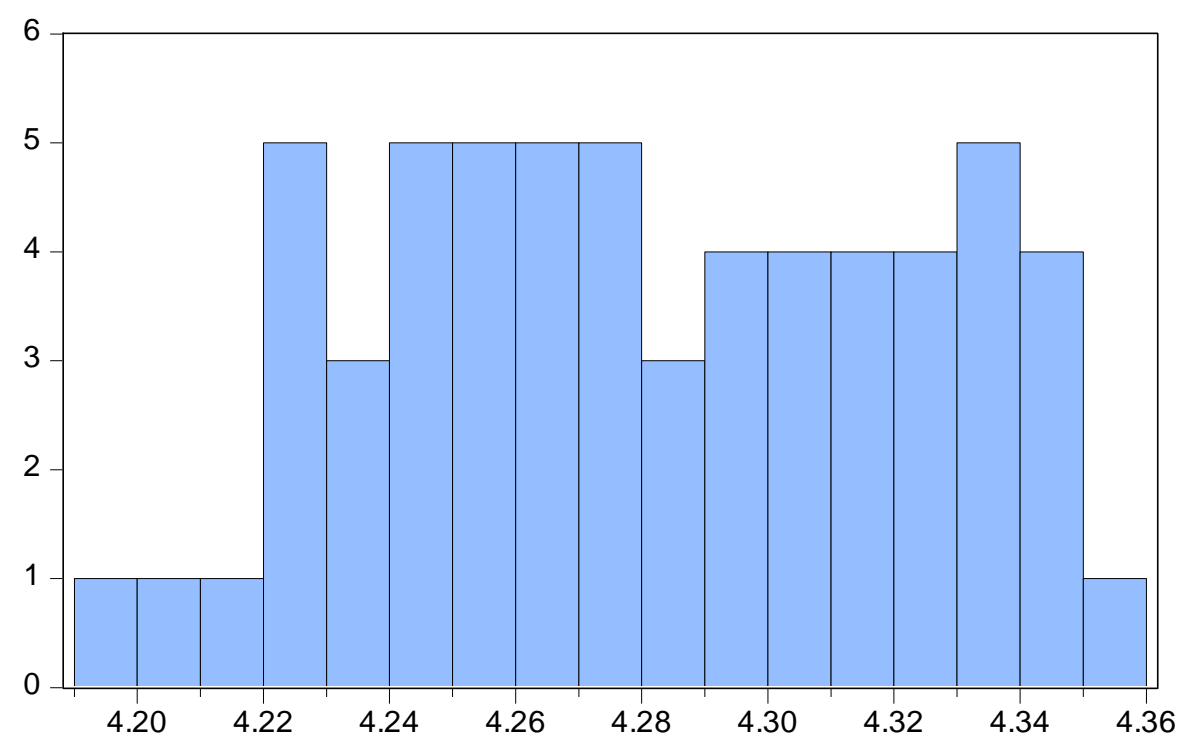

Series: HDI

Sample 2003Q1 2017Q4 Observations 60

Mean

4.281462

Median

4.277753

Maximum

4.350965

Minimum

4.195890

Std. Dev.

0.041373

Skewness $\quad-0.029073$

Kurtosis

1.941805

Jarque-Bera $\quad 2.807893$

Probability $\quad 0.245626$

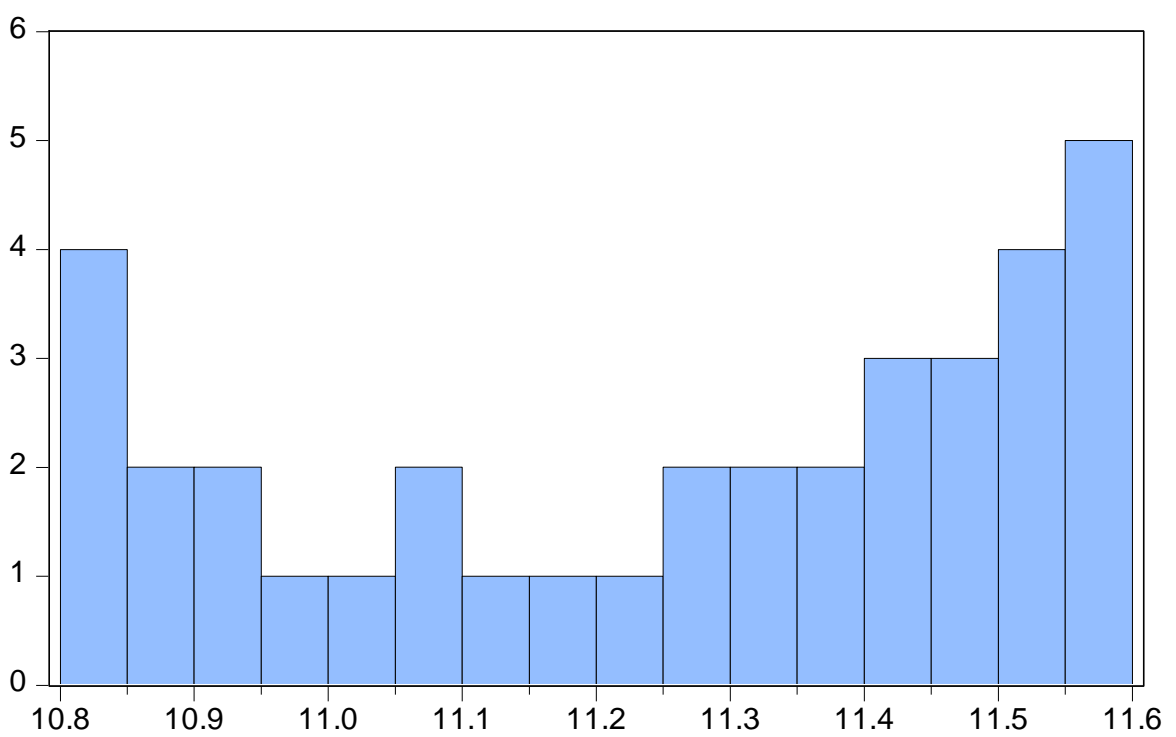

Series: HEALTH

Sample 2009Q1 2017Q4

Observations 36

Mean

11.25127

Median

11.32491

Maximum

11.55356

Minimum

10.81207

Std. Dev.

0.268516

Skewness

$-0.428224$

Kurtosis

1.680672

Jarque-Bera

3.711194

Probability

0.156360

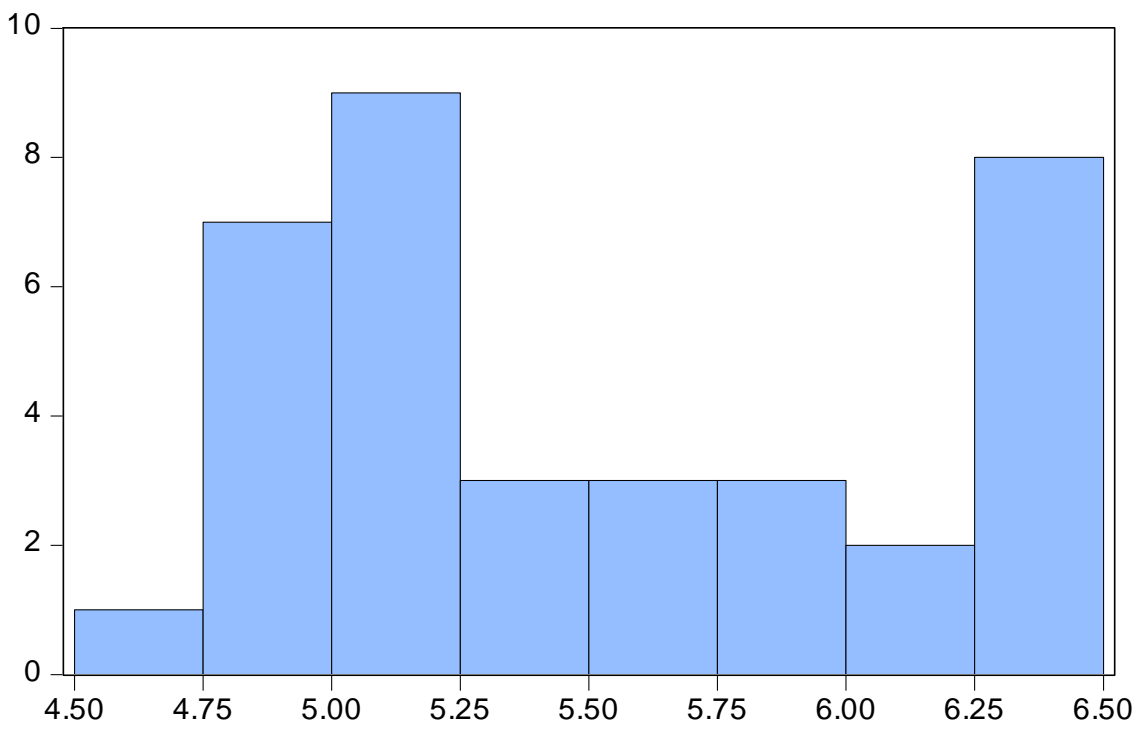

Series: EG

Sample 2009Q1 2017Q4

Observations 36

Mean

5.524722

Median

5.357500

Maximum

6.490000

Minimum

4.630000

Std. Dev.

0.591106

Skewness

0.365740

Kurtosis

1.576527

Jarque-Bera

3.842006

Probability

0.146460 


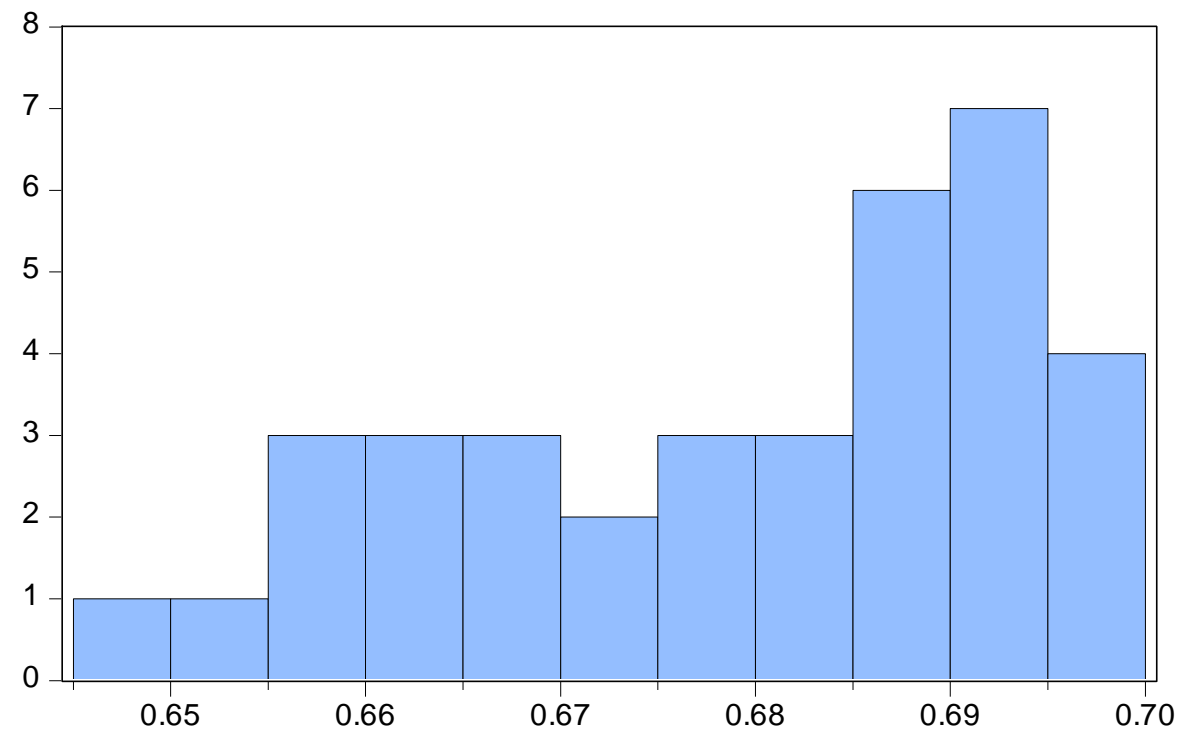

Series: HDI

Sample 2009Q1 2017Q4

Observations 36

Mean

Median

0.678875

Maximum

0.682750

Minimum

0.698000

Std. Dev.

0.649750

Skewness

0.014301

Kurtosis

486748

Jarque-Bera

Probability

\section{Regression Education Sector}

\begin{tabular}{|c|c|c|c|c|c|c|}
\hline \multicolumn{5}{|c|}{ Model Summary } & & \\
\hline \multirow{2}{*}{$\begin{array}{l}\text { Model } \\
1\end{array}$} & \multirow{2}{*}{$\begin{array}{l}\mathrm{R} \\
.990^{\mathrm{a}}\end{array}$} & \multirow{2}{*}{$\begin{array}{l}\text { R Square } \\
.981\end{array}$} & \multirow{2}{*}{$\begin{array}{l}\text { Adjusted R } \\
\text { Square } \\
.980\end{array}$} & \multicolumn{3}{|c|}{ Std. Error of the Estimate } \\
\hline & & & & .08081 & & \\
\hline \multicolumn{7}{|c|}{ a. Predictors: (Constant), HDI, Educ } \\
\hline \multicolumn{7}{|c|}{ ANOVA $^{\text {a }}$} \\
\hline \multicolumn{2}{|c|}{ Model } & Sum of Squares & $\mathrm{df}$ & Mean Square & $\mathrm{F}$ & Sig. \\
\hline \multirow[t]{3}{*}{1} & Regression & 19.181 & 1 & 19.181 & 2937.256 & $.000^{\mathrm{b}}$ \\
\hline & Residual & .379 & 58 & .007 & & \\
\hline & Total & 19.560 & 59 & & & \\
\hline \multicolumn{7}{|c|}{ a. Dependent Variable: EG } \\
\hline \multicolumn{7}{|c|}{ b. Predictors: (Constant), HDI, Educ } \\
\hline \multicolumn{7}{|c|}{ Coefficients $^{\mathrm{a}}$} \\
\hline \multirow{2}{*}{\multicolumn{2}{|c|}{ Model }} & \multicolumn{2}{|l|}{$\begin{array}{l}\text { Unstandardized } \\
\text { Coefficients }\end{array}$} & $\begin{array}{l}\text { Standardized } \\
\text { Coefficients } \\
\end{array}$ & $\mathrm{t}$ & Sig. \\
\hline & & $\mathrm{B}$ & Std. Error & Beta & & \\
\hline \multirow[t]{3}{*}{1} & (Constant) & -2.030 & .251 & & -8.100 & .000 \\
\hline & Educ & 20.594 & .380 & .990 & 54.196 & .000 \\
\hline & HDI & -2.030 & .251 & & -8.100 & .000 \\
\hline
\end{tabular}

\begin{tabular}{|l|l|l|l|l|l|l|}
\hline \multicolumn{2}{|l|}{ Model Summary } & R Square & $\begin{array}{l}\text { Adjusted R } \\
\text { Square }\end{array}$ & \multicolumn{2}{l|}{ Std. Error of the Estimate } \\
\hline Model & R & .248 & .49846 & & \\
\hline 1 & $.523^{\mathrm{a}}$ & .273 & \multicolumn{5}{|l}{} \\
\hline \multicolumn{6}{|l}{ a. Predictors: (Constant), HDI, Educ }
\end{tabular}




\begin{tabular}{|c|c|c|c|c|c|c|}
\hline \multicolumn{7}{|c|}{ ANOVA $^{a}$} \\
\hline \multicolumn{2}{|c|}{ Model } & Sum of Squares & $\mathrm{df}$ & Mean Square & $\mathrm{F}$ & Sig. \\
\hline \multirow[t]{3}{*}{1} & Regression & 5.324 & 2 & 2.662 & 10.714 & $.000^{\mathrm{b}}$ \\
\hline & Residual & 14.162 & 57 & .248 & & \\
\hline & Total & 19.486 & 59 & & & \\
\hline \multicolumn{7}{|c|}{ a. Dependent Variable: EG } \\
\hline \multicolumn{7}{|c|}{ b. Predictors: (Constant), HDI, Educ } \\
\hline \multicolumn{7}{|c|}{ Coefficients $^{\mathrm{a}}$} \\
\hline \multirow{2}{*}{\multicolumn{2}{|c|}{ Model }} & \multicolumn{2}{|l|}{$\begin{array}{l}\text { Unstandardized } \\
\text { Coefficients }\end{array}$} & $\begin{array}{l}\text { Standardized } \\
\text { Coefficients }\end{array}$ & \multirow[t]{2}{*}{$\mathrm{t}$} & \multirow[t]{2}{*}{ Sig. } \\
\hline & & $\mathrm{B}$ & Std. Error & Beta & & \\
\hline \multirow[t]{3}{*}{1} & (Constant) & 12.113 & 2.257 & & 5.367 & .000 \\
\hline & Educ & 3.717 & .810 & 3.724 & 4.589 & .000 \\
\hline & HDI & -75.129 & 16.844 & -3.619 & -4.460 & .000 \\
\hline
\end{tabular}

\section{Regression Health Sector}

\begin{tabular}{|c|c|c|c|c|c|c|}
\hline \multicolumn{5}{|c|}{ Model Summary } & & \\
\hline \multirow{3}{*}{$\begin{array}{r}\text { Model } \\
.994^{\mathrm{a}}\end{array}$} & \multirow{3}{*}{$\begin{array}{l}\mathrm{R} \\
.987 \\
\end{array}$} & \multirow{3}{*}{$\begin{array}{l}\text { R Square } \\
\\
.987\end{array}$} & \multirow{3}{*}{$\begin{array}{l}\begin{array}{l}\text { Adjusted R } \\
\text { Square }\end{array} \\
.03051\end{array}$} & \multicolumn{3}{|c|}{ Std. Error of the Estimate } \\
\hline & & & & & & \\
\hline & & & & $.994^{\mathrm{a}}$ & & \\
\hline \multicolumn{7}{|c|}{ a. Predictors: (Constant), HDI, Educ } \\
\hline \multicolumn{7}{|c|}{ ANOVA $^{\text {a }}$} \\
\hline \multicolumn{2}{|c|}{ Model } & Sum of Squares & $\mathrm{df}$ & Mean Square & $\mathrm{F}$ & Sig. \\
\hline \multirow[t]{3}{*}{1} & Regression & 2.492 & 1 & 2.492 & 2676.673 & $.000^{\mathrm{b}}$ \\
\hline & Residual & .032 & 34 & .001 & & \\
\hline & Total & 2.524 & 35 & & & \\
\hline \multicolumn{7}{|c|}{ a. Dependent Variable: EG } \\
\hline \multicolumn{7}{|c|}{ b. Predictors: (Constant), HDI, Educ } \\
\hline \multicolumn{7}{|c|}{ Coefficients $^{\mathrm{a}}$} \\
\hline \multirow{3}{*}{\multicolumn{2}{|c|}{ Model }} & \multirow{2}{*}{\multicolumn{2}{|c|}{$\begin{array}{l}\text { Unstandardized } \\
\text { Coefficients }\end{array}$}} & Standardized & \multirow[t]{3}{*}{$\mathrm{t}$} & \multirow[t]{3}{*}{ Sig. } \\
\hline & & & & Coefficients & & \\
\hline & & B & Std. Error & Beta & & \\
\hline \multirow[t]{2}{*}{1} & (Constant) & -1.415 & .245 & & -5.778 & .000 \\
\hline & HDI & 18.657 & .361 & .994 & 51.737 & .000 \\
\hline
\end{tabular}

\begin{tabular}{|l|l|l|l|l|l|}
\hline \multicolumn{5}{|l|}{ Model Summary } & \multicolumn{1}{l|}{} \\
\hline Model & $\mathrm{R}$ & R Square & $\begin{array}{l}\text { Adjusted R } \\
\text { Square }\end{array}$ & \multicolumn{2}{l|}{ Std. Error of the Estimate } \\
\hline 1 & $.552^{\mathrm{a}}$ & .304 & .262 & .50773 & \\
\hline \multicolumn{2}{|c|}{ a. Predictors: (Constant), HDI, Educ } \\
\hline
\end{tabular}




\begin{tabular}{|c|c|c|c|c|c|c|}
\hline \multicolumn{7}{|c|}{ ANOVA $^{a}$} \\
\hline \multicolumn{2}{|c|}{ Model } & Sum of Squares & $\mathrm{df}$ & Mean Square & $\mathrm{F}$ & Sig. \\
\hline \multirow[t]{3}{*}{1} & Regression & 3.722 & 2 & 1.861 & 7.219 & $.003^{b}$ \\
\hline & Residual & 8.507 & 33 & .258 & & \\
\hline & Total & 12.229 & 35 & & & \\
\hline \multicolumn{7}{|c|}{ a. Dependent Variable: EG } \\
\hline \multicolumn{7}{|c|}{ b. Predictors: (Constant), HDI, Educ } \\
\hline \multicolumn{7}{|c|}{ Coefficients $^{\mathrm{a}}$} \\
\hline \multirow{2}{*}{\multicolumn{2}{|c|}{ Model }} & \multicolumn{2}{|l|}{$\begin{array}{l}\text { Unstandardized } \\
\text { Coefficients }\end{array}$} & $\begin{array}{l}\text { Standardized } \\
\text { Coefficients }\end{array}$ & \multirow[t]{2}{*}{$\mathrm{t}$} & \multirow[t]{2}{*}{ Sig. } \\
\hline & & $\mathrm{B}$ & Std. Error & Beta & & \\
\hline \multirow[t]{3}{*}{1} & (Constant) & 172.442 & 57.805 & & 2.983 & .005 \\
\hline & Educ & 3.752 & 1.715 & 1.705 & 2.188 & .036 \\
\hline & HDI & -48.532 & 17.788 & -2.126 & -2.728 & .010 \\
\hline
\end{tabular}

\section{Level Unit Root}

\begin{tabular}{|c|c|c|c|c|}
\hline \multicolumn{5}{|c|}{ Null Hypothesis: Unit root (individual unit root process) } \\
\hline \multicolumn{3}{|c|}{ Series: EDUC, EG, EYS } & & \\
\hline \multicolumn{3}{|c|}{ Date: 09/22/19 Time: $14: 54$} & & \\
\hline \multicolumn{3}{|c|}{ Sample: 2003Q1 2017Q4 } & & \\
\hline \multicolumn{4}{|c|}{ Exogenous variables: Individual effects } & \\
\hline \multicolumn{4}{|c|}{ Automatic selection of maximum lags } & \\
\hline \multicolumn{5}{|c|}{ Automatic lag length selection based on SIC: 1 to 5} \\
\hline \multicolumn{4}{|c|}{ Total number of observations: 170} & \\
\hline \multicolumn{3}{|c|}{ Cross-sections included: 3} & & \\
\hline \multicolumn{3}{|l|}{ Method } & Statistic & Prob.** \\
\hline \multicolumn{3}{|c|}{ ADF - Fisher Chi-square } & 15.1317 & 0.0193 \\
\hline \multicolumn{3}{|c|}{ ADF - Choi Z-stat } & -2.15330 & 0.0156 \\
\hline \multicolumn{5}{|c|}{ ** Probabilities for Fisher tests are computed using an asymptotic Chi } \\
\hline \multicolumn{5}{|c|}{-square distribution. All other tests assume asymptotic normality. } \\
\hline \multicolumn{4}{|c|}{ Intermediate ADF test results UNTITLED } & \\
\hline Series & Prob. & Lag & Max Lag & Obs \\
\hline EDUC & 0.0292 & 5 & 10 & 54 \\
\hline EG & 0.0370 & 1 & 10 & 58 \\
\hline EYS & 0.4803 & 1 & 10 & 58 \\
\hline
\end{tabular}

\begin{tabular}{|l|l|l|}
\hline \multicolumn{3}{|l|}{ Null Hypothesis: Unit root (individual unit root process) } \\
\hline Series: EG, ELB, HEALTH & & \\
\hline Date: 09/22/19 Time: $14: 49$ & & \\
\hline Sample: 2009Q1 2017Q4 & & \\
\hline Exogenous variables: Individual effects & \\
\hline
\end{tabular}


Automatic selection of maximum lags

Automatic lag length selection based on SIC: 1 to 5

Total number of observations: 98

Cross-sections included: 3

Method

ADF - Fisher Chi-square

ADF - Choi Z-stat

0.4890

** Probabilities for Fisher tests are computed using an asymptotic Chi -square distribution. All other tests assume asymptotic normality.

\begin{tabular}{|c|c|c|c|c|}
\hline \multicolumn{4}{|c|}{ Intermediate ADF test results UNTITLED } & \\
\hline Series & Prob. & Lag & Max Lag & Obs \\
\hline EG & 0.1766 & 5 & 8 & 30 \\
\hline ELB & 0.9986 & 1 & 8 & 34 \\
\hline HEALTH & 0.0174 & 1 & 8 & 34 \\
\hline
\end{tabular}

\section{$1^{\text {st }}$ Difference Unit Root}

\begin{tabular}{|c|c|c|c|c|}
\hline \multicolumn{5}{|c|}{ Null Hypothesis: Unit root (individual unit root process) } \\
\hline \multicolumn{3}{|c|}{ Series: LEB, HEALTH, EG } & & \\
\hline Date: 09/22/19 & \multicolumn{2}{|c|}{ Time: $14: 51$} & & \\
\hline \multicolumn{3}{|c|}{ Sample: 2009Q1 2017Q4 } & & \\
\hline \multicolumn{4}{|c|}{ Exogenous variables: Individual effects } & \\
\hline \multicolumn{4}{|c|}{ Automatic selection of maximum lags } & \\
\hline \multicolumn{5}{|c|}{ Automatic lag length selection based on SIC: 0 to 4} \\
\hline \multicolumn{4}{|c|}{ Total number of observations: 98} & \\
\hline \multicolumn{3}{|c|}{ Cross-sections included: 3} & & \\
\hline \multicolumn{2}{|l|}{ Method } & & Statistic & Prob.** \\
\hline \multicolumn{3}{|c|}{ ADF - Fisher Chi-square } & 5.43019 & 0.4899 \\
\hline \multicolumn{3}{|c|}{ ADF - Choi Z-stat } & -0.02754 & 0.4890 \\
\hline \multicolumn{5}{|c|}{ ** Probabilities for Fisher tests are computed using an asymptotic Chi } \\
\hline \multicolumn{5}{|c|}{-square distribution. All other tests assume asymptotic normality. } \\
\hline \multicolumn{4}{|c|}{ Intermediate ADF test results D(UNTITLED) } & \\
\hline Series & Prob. & Lag & Max Lag & Obs \\
\hline $\mathrm{D}(\mathrm{LEB})$ & 0.7195 & 0 & 8 & 34 \\
\hline D(HEALTH) & 0.6826 & 0 & 8 & 34 \\
\hline $\mathrm{D}(\mathrm{EG})$ & 0.1348 & 4 & 8 & 30 \\
\hline
\end{tabular}

\begin{tabular}{|l|l|l|}
\hline \multicolumn{3}{|l|}{ Null Hypothesis: Unit root (individual unit root process) } \\
\hline Series: EDUC, EG, EYS & & \\
\hline Date: 09/22/19 Time: 14:56 & & \\
\hline Sample: 2003Q1 2017Q4 & & \\
\hline Exogenous variables: Individual effects & \\
\hline
\end{tabular}




\begin{tabular}{|c|c|c|c|c|}
\hline \multicolumn{4}{|c|}{ Automatic selection of maximum lags } & \\
\hline \multicolumn{5}{|c|}{ Automatic lag length selection based on SIC: 0 to 4} \\
\hline \multicolumn{4}{|c|}{ Total number of observations: 170} & \\
\hline \multicolumn{3}{|c|}{ Cross-sections included: 3} & & \\
\hline \multicolumn{2}{|l|}{ Method } & & Statistic & Prob.** \\
\hline \multicolumn{3}{|c|}{ ADF - Fisher Chi-square } & 9.75498 & 0.1354 \\
\hline \multicolumn{3}{|c|}{ ADF - Choi Z-stat } & -1.08801 & 0.1383 \\
\hline \multicolumn{5}{|c|}{ ** Probabilities for Fisher tests are computed using an asymptotic Chi } \\
\hline \multicolumn{5}{|c|}{-square distribution. All other tests assume asymptotic normality. } \\
\hline \multicolumn{4}{|c|}{ Intermediate ADF test results D(UNTITLED) } & \\
\hline Series & Prob. & Lag & Max Lag & Obs \\
\hline $\mathrm{D}(\mathrm{EDUC})$ & 0.5600 & 4 & 10 & 54 \\
\hline $\mathrm{D}(\mathrm{EG})$ & 0.0317 & 0 & 10 & 58 \\
\hline $\mathrm{D}(\mathrm{EYS})$ & 0.4289 & 0 & 10 & 58 \\
\hline
\end{tabular}

\section{$2^{\text {nd }}$ Difference Unit root}

\begin{tabular}{|c|c|c|c|c|}
\hline \multicolumn{5}{|c|}{ Null Hypothesis: Unit root (individual unit root process) } \\
\hline \multicolumn{3}{|c|}{ Series: EDUC, EG, EYS } & & \\
\hline \multicolumn{3}{|c|}{ Date: $09 / 22 / 19 \quad$ Time: $14: 57$} & & \\
\hline \multicolumn{3}{|c|}{ Sample: 2003Q1 2017Q4 } & & \\
\hline \multicolumn{4}{|c|}{ Exogenous variables: Individual effects } & \\
\hline \multicolumn{4}{|c|}{ Automatic selection of maximum lags } & \\
\hline \multicolumn{5}{|c|}{ Automatic lag length selection based on SIC: 0 to 7} \\
\hline \multicolumn{4}{|c|}{ Total number of observations: 164} & \\
\hline \multicolumn{3}{|c|}{ Cross-sections included: 3} & & \\
\hline \multicolumn{2}{|l|}{ Method } & & Statistic & Prob.** \\
\hline \multicolumn{3}{|c|}{ ADF - Fisher Chi-square } & 88.5535 & 0.0000 \\
\hline \multicolumn{3}{|c|}{ ADF - Choi Z-stat } & -8.45639 & 0.0000 \\
\hline \multicolumn{5}{|c|}{ ** Probabilities for Fisher tests are computed using an asymptotic Chi } \\
\hline \multicolumn{5}{|c|}{-square distribution. All other tests assume asymptotic normality. } \\
\hline \multicolumn{4}{|c|}{ Intermediate ADF test results D(UNTITLED,2) } & \\
\hline Series & Prob. & Lag & Max Lag & Obs \\
\hline $\mathrm{D}(\mathrm{EDUC}, 2)$ & 0.0001 & 7 & 10 & 50 \\
\hline $\mathrm{D}(\mathrm{EG}, 2)$ & 0.0000 & 0 & 10 & 57 \\
\hline $\mathrm{D}(\mathrm{EYS}, 2)$ & 0.0000 & 0 & 10 & 57 \\
\hline
\end{tabular}

\begin{tabular}{|l|l|l|}
\hline \multicolumn{3}{|l|}{ Null Hypothesis: Unit root (individual unit root process) } \\
\hline Series: LEB, HEALTH, EG & & \\
\hline Date: 09/22/19 Time: $14: 58$ & & \\
\hline Sample: 2009Q1 2017Q4 & & \\
\hline Exogenous variables: Individual effects & \\
\hline
\end{tabular}




\begin{tabular}{|c|c|c|c|c|}
\hline \multicolumn{4}{|c|}{ Automatic selection of maximum lags } & \\
\hline \multicolumn{5}{|c|}{ Automatic lag length selection based on SIC: 0 to 3} \\
\hline \multicolumn{4}{|c|}{ Total number of observations: 96} & \\
\hline \multicolumn{3}{|c|}{ Cross-sections included: 3} & & \\
\hline \multicolumn{2}{|l|}{ Method } & & Statistic & Prob.** \\
\hline \multicolumn{3}{|c|}{ ADF - Fisher Chi-square } & 61.3846 & 0.0000 \\
\hline \multicolumn{3}{|c|}{ ADF - Choi Z-stat } & -6.87190 & 0.0000 \\
\hline \multicolumn{5}{|c|}{ ** Probabilities for Fisher tests are computed using an asymptotic Chi } \\
\hline \multicolumn{5}{|c|}{-square distribution. All other tests assume asymptotic normality. } \\
\hline \multicolumn{5}{|c|}{ Intermediate $\mathrm{ADF}$ test results $\mathrm{D}$ (UNTITLED,2) } \\
\hline Series & Prob. & Lag & Max Lag & Obs \\
\hline $\mathrm{D}(\mathrm{LEB}, 2)$ & 0.0000 & 0 & 7 & 33 \\
\hline D(HEALTH,2) & 0.0001 & 0 & 7 & 33 \\
\hline $\mathrm{D}(\mathrm{EG}, 2)$ & 0.0000 & 3 & 7 & 30 \\
\hline
\end{tabular}

\section{Long term}

\begin{tabular}{|c|c|c|c|c|}
\hline \multicolumn{3}{|c|}{ Dependent Variable: EG } & & \\
\hline \multicolumn{3}{|c|}{ Method: Least Squares } & & \\
\hline \multicolumn{3}{|c|}{ Date: 09/22/19 Time: 15:01 } & & \\
\hline \multicolumn{3}{|c|}{ Sample: 2003Q1 2017Q4 } & & \\
\hline \multicolumn{3}{|c|}{ Included observations: 60} & & \\
\hline Variable & Coefficient & Std. Error & t-Statistic & Prob. \\
\hline EDUC & 5.479062 & 0.611153 & 8.965130 & 0.0000 \\
\hline EYS & -32.67545 & 3.703513 & -8.822827 & 0.0000 \\
\hline $\mathrm{C}$ & 21.05039 & 2.179464 & 9.658519 & 0.0000 \\
\hline R-squared & 0.585543 & \multicolumn{2}{|c|}{ Mean dependent var } & 5.501083 \\
\hline Adjusted R-squared & 0.571000 & \multicolumn{2}{|c|}{ S.D. dependent var } & 0.574697 \\
\hline S.E. of regression & 0.376415 & \multicolumn{2}{|c|}{ Akaike info criterion } & 0.932460 \\
\hline Sum squared resid & 8.076248 & \multicolumn{2}{|c|}{ Schwarz criterion } & 1.037177 \\
\hline Log likelihood & -24.97380 & \multicolumn{2}{|c|}{ Hannan-Quinn criter. } & 0.973421 \\
\hline F-statistic & 40.26461 & \multicolumn{2}{|c|}{ Durbin-Watson stat } & 0.226913 \\
\hline $\operatorname{Prob}($ F-statistic) & 0.000000 & & & \\
\hline
\end{tabular}

\begin{tabular}{|c|c|c|c|c|}
\hline \multicolumn{3}{|c|}{ Dependent Variable: EG } & & \\
\hline \multicolumn{3}{|c|}{ Method: Least Squares } & & \\
\hline \multicolumn{3}{|c|}{ Date: 09/22/19 Time: 15:04 } & & \\
\hline \multicolumn{3}{|c|}{ Sample: 2009Q1 2017Q4 } & & \\
\hline \multicolumn{3}{|c|}{ Included observations: 36} & & \\
\hline Variable & Coefficient & Std. Error & $\mathrm{t}$-Statistic & Prob. \\
\hline LEB & -142.2290 & 59.67342 & -2.383456 & 0.0231 \\
\hline HEALTH & 2.676996 & 1.513503 & 1.768741 & 0.0862 \\
\hline $\mathrm{C}$ & 576.8128 & 235.7275 & 2.446948 & 0.0199 \\
\hline
\end{tabular}




\begin{tabular}{|c|c|c|c|}
\hline R-squared & 0.272646 & Mean dependent var & 5.524722 \\
\hline Adjusted R-squared & 0.228564 & S.D. dependent var & 0.591106 \\
\hline S.E. of regression & 0.519177 & Akaike info criterion & 1.606512 \\
\hline Sum squared resid & 8.894979 & Schwarz criterion & 1.738472 \\
\hline Log likelihood & -25.91721 & Hannan-Quinn criter. & 1.652569 \\
\hline F-statistic & 6.184952 & Durbin-Watson stat & 0.127806 \\
\hline Prob(F-statistic) & 0.005234 & & \\
\hline
\end{tabular}

\section{ADF Cointegeration Test}

\begin{tabular}{|c|c|c|c|c|}
\hline \multicolumn{4}{|c|}{ Null Hypothesis: RES has a unit root } & \\
\hline \multicolumn{3}{|l|}{ Exogenous: Constant } & & \\
\hline \multicolumn{5}{|c|}{ Lag Length: 9 (Automatic - based on SIC, maxlag=10) } \\
\hline & & & t-Statistic & Prob.* \\
\hline \multicolumn{3}{|c|}{ Augmented Dickey-Fuller test statistic } & -3.164004 & 0.0282 \\
\hline \multirow[t]{3}{*}{ Test critical values: } & $1 \%$ level & & -3.568308 & \\
\hline & $5 \%$ level & & -2.921175 & \\
\hline & $10 \%$ level & & -2.598551 & \\
\hline \multicolumn{4}{|c|}{ *MacKinnon (1996) one-sided p-values. } & \\
\hline \multicolumn{4}{|c|}{ Augmented Dickey-Fuller Test Equation } & \\
\hline \multicolumn{3}{|c|}{ Dependent Variable: D(RES) } & & \\
\hline \multicolumn{3}{|c|}{ Method: Least Squares } & & \\
\hline \multicolumn{3}{|c|}{ Date: 09/22/19 Time: $15: 18$} & & \\
\hline \multicolumn{4}{|c|}{ Sample (adjusted): 2005Q3 2017Q4 } & \\
\hline \multicolumn{4}{|c|}{ Included observations: 50 after adjustments } & \\
\hline Variable & Coefficient & Std. Error & t-Statistic & Prob. \\
\hline RES(-1) & -0.261119 & 0.082528 & -3.164004 & 0.0030 \\
\hline $\mathrm{D}(\mathrm{RES}(-1))$ & 0.945093 & 0.130268 & 7.254990 & 0.0000 \\
\hline $\mathrm{D}(\mathrm{RES}(-2))$ & 0.171459 & 0.139573 & 1.228457 & 0.2266 \\
\hline $\mathrm{D}(\mathrm{RES}(-3))$ & 0.171107 & 0.137984 & 1.240052 & 0.2224 \\
\hline $\mathrm{D}(\mathrm{RES}(-4))$ & -0.647513 & 0.138130 & -4.687699 & 0.0000 \\
\hline $\mathrm{D}(\mathrm{RES}(-5))$ & 0.741250 & 0.152312 & 4.866648 & 0.0000 \\
\hline $\mathrm{D}(\mathrm{RES}(-6))$ & 0.086894 & 0.130541 & 0.665642 & 0.5096 \\
\hline $\mathrm{D}(\mathrm{RES}(-7))$ & 0.086623 & 0.129696 & 0.667894 & 0.5081 \\
\hline $\mathrm{D}(\mathrm{RES}(-8))$ & -0.646002 & 0.130112 & -4.964982 & 0.0000 \\
\hline D(RES(-9)) & 0.610199 & 0.122128 & 4.996375 & 0.0000 \\
\hline $\mathrm{C}$ & 0.002199 & 0.012203 & 0.180161 & 0.8580 \\
\hline R-squared & 0.832080 & \multicolumn{2}{|c|}{ Mean dependent var } & 0.002478 \\
\hline Adjusted R-squared & 0.789023 & \multicolumn{2}{|c|}{ S.D. dependent var } & 0.187448 \\
\hline S.E. of regression & 0.086099 & \multicolumn{2}{|c|}{ Akaike info criterion } & -1.875103 \\
\hline Sum squared resid & 0.289107 & \multicolumn{2}{|c|}{ Schwarz criterion } & -1.454458 \\
\hline Log likelihood & 57.87757 & \multicolumn{2}{|c|}{ Hannan-Quinn criter. } & -1.714919 \\
\hline F-statistic & 19.32528 & \multicolumn{2}{|c|}{ Durbin-Watson stat } & 2.095436 \\
\hline
\end{tabular}


$\operatorname{Prob}($ F-statistic $)$

0.000000

Null Hypothesis: RES has a unit root

Exogenous: Constant

Lag Length: 5 (Automatic - based on SIC, maxlag=9)

\begin{tabular}{|l|l|l|l|l|}
\hline & & & t-Statistic & Prob.* \\
\hline Augmented Dickey-Fuller test statistic & -3.014767 & 0.0449 \\
\hline Test critical values: & $1 \%$ level & & -3.670170 & \\
\hline & $5 \%$ level & & -2.963972 & \\
\hline & $10 \%$ level & & -2.621007 & \\
\hline
\end{tabular}

*MacKinnon (1996) one-sided p-values.

Augmented Dickey-Fuller Test Equation

Dependent Variable: D(RES)

Method: Least Squares

Date: 09/22/19 Time: 15:16

Sample (adjusted): 2010Q3 2017Q4

Included observations: 30 after adjustments

\begin{tabular}{|c|c|c|c|c|}
\hline Variable & Coefficient & Std. Error & t-Statistic & Prob. \\
\hline $\operatorname{RES}(-1)$ & -0.101737 & 0.033746 & -3.014767 & 0.0062 \\
\hline $\mathrm{D}(\operatorname{RES}(-1))$ & 0.697941 & 0.165286 & 4.222634 & 0.0003 \\
\hline $\mathrm{D}(\operatorname{RES}(-2))$ & 0.167929 & 0.161617 & 1.039055 & 0.3096 \\
\hline $\mathrm{D}(\operatorname{RES}(-3))$ & 0.046893 & 0.103480 & 0.453165 & 0.6547 \\
\hline $\mathrm{D}(\operatorname{RES}(-4))$ & -0.240001 & 0.103493 & -2.319007 & 0.0296 \\
\hline $\mathrm{D}(\operatorname{RES}(-5))$ & 0.263747 & 0.089244 & 2.955363 & 0.0071 \\
\hline $\mathrm{C}$ & 0.004736 & 0.011049 & 0.428629 & 0.6722 \\
\hline R-squared & 0.871287 & \multicolumn{2}{|c|}{ Mean dependent var } & 0.021666 \\
\hline Adjusted R-squared & 0.837709 & \multicolumn{2}{|c|}{ S.D. dependent var } & 0.141902 \\
\hline S.E. of regression & 0.057166 & \multicolumn{2}{|c|}{ Akaike info criterion } & -2.684757 \\
\hline Sum squared resid & 0.075162 & \multicolumn{2}{|c|}{ Schwarz criterion } & -2.357811 \\
\hline Log likelihood & 47.27135 & \multicolumn{2}{|c|}{ Hannan-Quinn criter. } & -2.580164 \\
\hline F-statistic & 25.94864 & \multicolumn{2}{|c|}{ Durbin-Watson stat } & 2.300310 \\
\hline Prob(F-statistic) & 0.000000 & & & \\
\hline
\end{tabular}

\section{Short term}

\begin{tabular}{|c|c|c|c|c|}
\hline \multicolumn{3}{|c|}{ Dependent Variable: D(D(EG)) } & & \\
\hline \multicolumn{3}{|c|}{ Method: Least Squares } & & \\
\hline \multicolumn{3}{|c|}{ Date: 09/23/19 Time: 09:35 } & & \\
\hline \multicolumn{4}{|c|}{ Sample (adjusted): 2009Q3 2017Q4 } & \\
\hline \multicolumn{4}{|c|}{ Included observations: 34 after adjustments } & \\
\hline Variable & Coefficient & Std. Error & t-Statistic & Prob. \\
\hline $\mathrm{D}(\mathrm{D}(\mathrm{HEALTH}))$ & 14.57191 & 3.507910 & 4.154016 & 0.0002 \\
\hline $\mathrm{D}(\mathrm{D}(\mathrm{LEB}))$ & 724.2549 & 597.0636 & 1.213028 & 0.2346 \\
\hline
\end{tabular}




\begin{tabular}{|l|l|l|l|l|}
\hline LTRRESID & -0.088459 & 0.039099 & -2.262440 & 0.0311 \\
\hline C & 0.011952 & 0.019401 & 0.616068 & 0.5425 \\
\hline R-squared & 0.458824 & Mean dependent var & 0.010441 \\
\hline Adjusted R-squared & 0.404706 & S.D. dependent var & 0.145804 \\
\hline S.E. of regression & 0.112496 & Akaike info criterion & -1.421672 \\
\hline Sum squared resid & 0.379659 & Schwarz criterion & -1.242100 \\
\hline Log likelihood & 28.16842 & Hannan-Quinn criter. & -1.360433 \\
\hline F-statistic & 8.478261 & Durbin-Watson stat & 2.383645 \\
\hline Prob(F-statistic) & 0.000314 & \multicolumn{4}{|l}{} \\
\hline
\end{tabular}

\begin{tabular}{|c|c|c|c|c|}
\hline \multicolumn{3}{|c|}{ Dependent Variable: D(D(EG)) } & & \\
\hline \multicolumn{3}{|c|}{ Method: Least Squares } & & \\
\hline \multicolumn{3}{|c|}{ Date: 09/23/19 Time: 09:29 } & & \\
\hline \multicolumn{4}{|c|}{ Sample (adjusted): 2003Q3 2017Q4 } & \\
\hline \multicolumn{4}{|c|}{ Included observations: 58 after adjustments } & \\
\hline Variable & Coefficient & Std. Error & t-Statistic & Prob. \\
\hline $\mathrm{D}(\mathrm{D}(\mathrm{EDUC}))$ & 2.263022 & 1.215874 & 1.861230 & 0.0682 \\
\hline $\mathrm{D}(\mathrm{D}(\mathrm{EYS}))$ & 4.441259 & 20.36851 & 0.218045 & 0.8282 \\
\hline LTRESID & -0.124189 & 0.046630 & -2.663289 & 0.0102 \\
\hline $\mathrm{C}$ & 0.002254 & 0.016524 & 0.136414 & 0.8920 \\
\hline R-squared & 0.140830 & \multicolumn{2}{|c|}{ Mean dependent var } & -0.001034 \\
\hline Adjusted R-squared & 0.093099 & \multicolumn{2}{|c|}{ S.D. dependent var } & 0.131430 \\
\hline S.E. of regression & 0.125163 & \multicolumn{2}{|c|}{ Akaike info criterion } & -1.251930 \\
\hline Sum squared resid & 0.845950 & \multicolumn{2}{|c|}{ Schwarz criterion } & -1.109831 \\
\hline Log likelihood & 40.30598 & \multicolumn{2}{|c|}{ Hannan-Quinn criter. } & -1.196580 \\
\hline F-statistic & 2.950461 & \multicolumn{2}{|c|}{ Durbin-Watson stat } & 2.307903 \\
\hline $\operatorname{Prob}(\mathrm{F}$-statistic) & 0.040732 & & & \\
\hline
\end{tabular}

\section{Linearity Test}

\begin{tabular}{|c|c|c|c|c|}
\hline \multicolumn{3}{|c|}{ Ramsey RESET Test } & & \\
\hline \multicolumn{3}{|c|}{ Equation: UNTITLED } & & \\
\hline \multicolumn{4}{|c|}{ Specification: EG HEALTH LEB C } & \\
\hline \multicolumn{4}{|c|}{ Omitted Variables: Squares of fitted values } & \\
\hline & Value & df & Probability & \\
\hline t-statistic & 1.078531 & 32 & 0.2889 & \\
\hline F-statistic & 1.163229 & $(1,32)$ & 0.2889 & \\
\hline Likelihood ratio & 1.285409 & 1 & 0.2569 & \\
\hline \multicolumn{4}{|l|}{ F-test summary: } & \\
\hline & Sum of Sq. & df & Mean Squares & \\
\hline Test SSR & 0.311999 & 1 & 0.311999 & \\
\hline Restricted SSR & 8.894979 & 33 & 0.269545 & \\
\hline Unrestricted SSR & 8.582980 & 32 & 0.268218 & \\
\hline
\end{tabular}




\begin{tabular}{|c|c|c|c|c|}
\hline Unrestricted SSR & 8.582980 & 32 & 0.268218 & \\
\hline \multicolumn{5}{|l|}{ LR test summary: } \\
\hline & Value & df & & \\
\hline Restricted LogL & -25.91721 & 33 & & \\
\hline Unrestricted $\log \mathrm{L}$ & -25.27451 & 32 & & \\
\hline \multicolumn{5}{|c|}{ Unrestricted Test Equation: } \\
\hline \multicolumn{5}{|c|}{ Dependent Variable: EG } \\
\hline \multicolumn{5}{|c|}{ Method: Least Squares } \\
\hline \multicolumn{5}{|c|}{ Date: 09/23/19 Time: 09:47 } \\
\hline \multicolumn{5}{|c|}{ Sample: 2009Q1 2017Q4 } \\
\hline \multicolumn{5}{|c|}{ Included observations: 36} \\
\hline Variable & Coefficient & Std. Error & t-Statistic & Prob. \\
\hline HEALTH & -26.21219 & 26.82820 & -0.977039 & 0.3359 \\
\hline LEB & 1409.122 & 1439.624 & 0.978813 & 0.3350 \\
\hline $\mathrm{C}$ & -5689.788 & 5815.068 & -0.978456 & 0.3352 \\
\hline FITTED^2 & 1.039858 & 0.964143 & 1.078531 & 0.2889 \\
\hline R-squared & 0.298158 & \multicolumn{2}{|c|}{ Mean dependent var } & 5.524722 \\
\hline Adjusted R-squared & 0.232361 & \multicolumn{2}{|c|}{ S.D. dependent var } & 0.591106 \\
\hline S.E. of regression & 0.517898 & \multicolumn{2}{|c|}{ Akaike info criterion } & 1.626361 \\
\hline Sum squared resid & 8.582980 & \multicolumn{2}{|c|}{ Schwarz criterion } & 1.802308 \\
\hline Log likelihood & -25.27451 & \multicolumn{2}{|c|}{ Hannan-Quinn criter. } & 1.687772 \\
\hline F-statistic & 4.531440 & \multicolumn{2}{|c|}{ Durbin-Watson stat } & 0.111646 \\
\hline Prob(F-statistic) & 0.009312 & & & \\
\hline
\end{tabular}

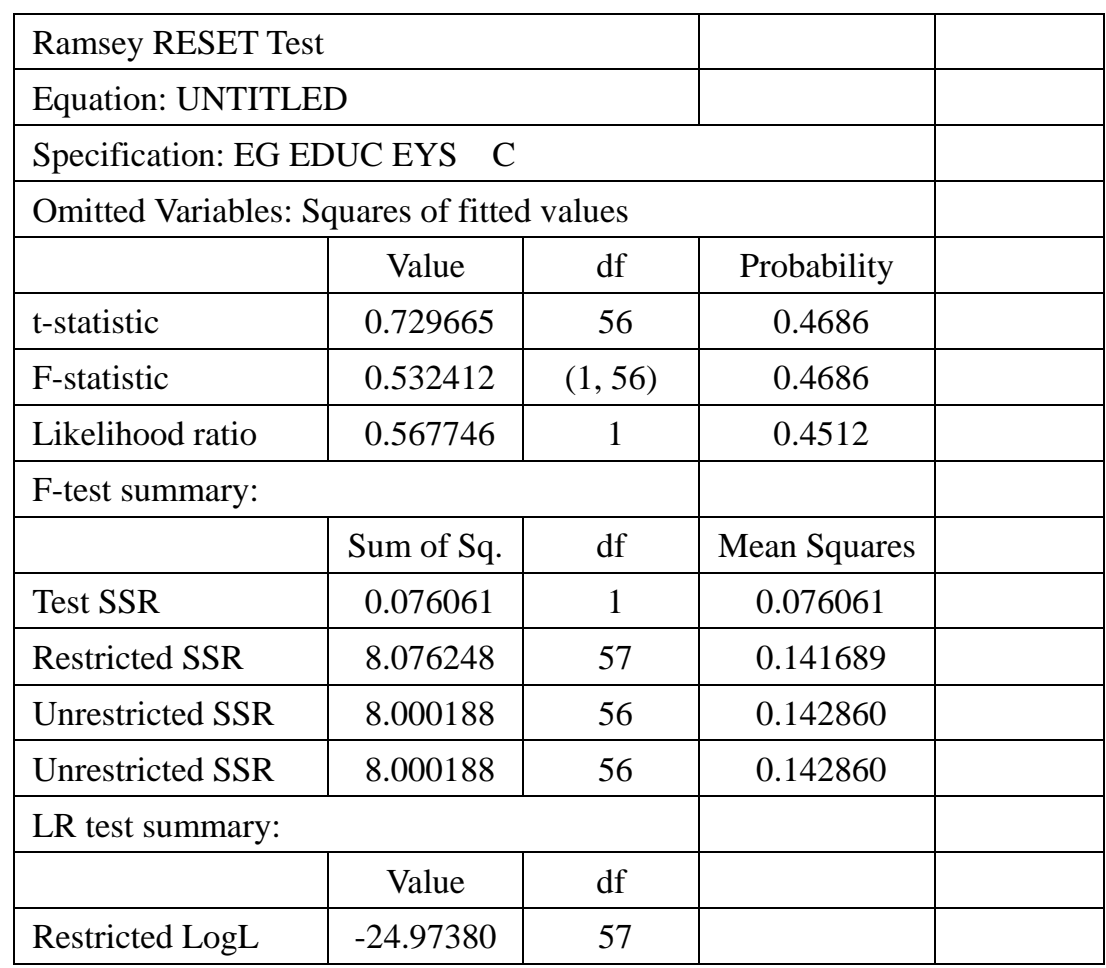




\begin{tabular}{|c|c|c|c|c|}
\hline Unrestricted LogL & -24.68993 & 56 & & \\
\hline \multicolumn{5}{|c|}{ Unrestricted Test Equation: } \\
\hline \multicolumn{5}{|c|}{ Dependent Variable: EG } \\
\hline \multicolumn{3}{|c|}{ Method: Least Squares } & & \\
\hline \multicolumn{5}{|c|}{ Date: 09/23/19 Time: 09:50 } \\
\hline \multicolumn{5}{|c|}{ Sample: 2003Q1 2017Q4 } \\
\hline \multicolumn{5}{|c|}{ Included observations: 60} \\
\hline Variable & Coefficient & Std. Error & t-Statistic & Prob. \\
\hline EDUC & -6.403254 & 16.29617 & -0.392930 & 0.6959 \\
\hline EYS & 38.22022 & 97.23302 & 0.393079 & 0.6958 \\
\hline $\mathrm{C}$ & -18.78422 & 54.63684 & -0.343801 & 0.7323 \\
\hline FITTED^2 & 0.198122 & 0.271524 & 0.729665 & 0.4686 \\
\hline R-squared & 0.589446 & \multicolumn{2}{|c|}{ Mean dependent var } & 5.501083 \\
\hline Adjusted R-squared & 0.567452 & \multicolumn{2}{|c|}{ S.D. dependent var } & 0.574697 \\
\hline S.E. of regression & 0.377969 & \multicolumn{2}{|c|}{ Akaike info criterion } & 0.956331 \\
\hline Sum squared resid & 8.000188 & \multicolumn{2}{|c|}{ Schwarz criterion } & 1.095954 \\
\hline Log likelihood & -24.68993 & \multicolumn{2}{|c|}{ Hannan-Quinn criter. } & 1.010945 \\
\hline F-statistic & 26.80034 & \multicolumn{2}{|c|}{ Durbin-Watson stat } & 0.236238 \\
\hline Prob(F-statistic) & 0.000000 & & & \\
\hline
\end{tabular}

\section{Heteroscedasticity Test}

\begin{tabular}{|l|l|l|l|l|}
\hline \multicolumn{5}{|l|}{ Heteroskedasticity Test: Breusch-Pagan-Godfrey } \\
\hline F-statistic & 1.448473 & \multicolumn{2}{l|}{ Prob. F(2,57) } & 0.2434 \\
\hline Obs*R-squared & 2.901930 & \multicolumn{2}{|c|}{ Prob. Chi-Square(2) } & 0.2343 \\
\hline Scaled explained SS & 2.728264 & \multicolumn{2}{|c|}{ Prob. Chi-Square(2) } & 0.2556 \\
\hline Test Equation: & & & \\
\hline Dependent Variable: RESID^2 & & & \\
\hline Method: Least Squares & & & \\
\hline Date: 09/23/19 Time: $09: 54$ & & & \\
\hline Sample: 2003Q1 2017Q4 & & \\
\hline Included observations: 60 & Coefficient & Std. Error & t-Statistic & Prob. \\
\hline Variable & 2.040651 & 1.125914 & 1.812440 & 0.0752 \\
\hline C & 0.470009 & 0.315722 & 1.488680 & 0.1421 \\
\hline EDUC & -3.040286 & 1.913239 & -1.589078 & 0.1176 \\
\hline EYS & 0.048365 & \multicolumn{2}{|c|}{ Mean dependent var } & 0.134604 \\
\hline R-squared & 0.014975 & S.D. dependent var & 0.195929 \\
\hline Adjusted R-squared & 1.448473 & Durbin-Watson stat & 0.703846 \\
\hline S.E. of regression & 0.194457 & Akaike info criterion & -0.388508 \\
\hline Sum squared resid & 2.155364 & Schwarz criterion & -0.283791 \\
\hline Log likelihood & 14.65524 & Hannan-Quinn criter. & -0.347547 \\
\hline F-statistic & 0.243445 & & & \\
\hline Prob(F-statistic) & & & \\
\hline
\end{tabular}




\begin{tabular}{|l|l|l|l|l|}
\hline \multicolumn{4}{|l|}{ Heteroskedasticity Test: Breusch-Pagan-Godfrey } \\
\hline F-statistic & 1.185538 & \multicolumn{2}{|l|}{ Prob. F(2,31) } & 0.3191 \\
\hline Obs*R-squared & 2.415763 & \multicolumn{2}{|l|}{ Prob. Chi-Square(2) } & 0.2988 \\
\hline Scaled explained SS & 1.069612 & \multicolumn{2}{|l|}{ Prob. Chi-Square(2) } & 0.5858 \\
\hline Test Equation: & & & \\
\hline Dependent Variable: RESID^2 & & \\
\hline Method: Least Squares & & & \\
\hline Date: 09/23/19 Time: 09:56 & & \\
\hline Sample (adjusted): 2009 Q3 2017Q4 & & \\
\hline Included observations: 34 after adjustments & & \\
\hline Variable & Coefficient & Std. Error & t-Statistic & Prob. \\
\hline C & 0.251477 & 0.044082 & 5.704741 & 0.0000 \\
\hline D(D(HEALTH)) & 9.125110 & 7.913842 & 1.153057 & 0.2577 \\
\hline D(D(LEB)) & -690.9173 & 1356.468 & -0.509350 & 0.6141 \\
\hline R-squared & 0.071052 & \multicolumn{2}{|l|}{ Mean dependent var } & 0.248529 \\
\hline Adjusted R-squared & 0.011120 & S.D. dependent var & 0.257463 \\
\hline S.E. of regression & 0.256027 & Akaike info criterion & 0.197032 \\
\hline Sum squared resid & 2.032049 & Schwarz criterion & 0.331711 \\
\hline Log likelihood & -0.349539 & Hannan-Quinn criter. & 0.242961 \\
\hline F-statistic & 1.185538 & Durbin-Watson stat & 0.787415 \\
\hline Prob(F-statistic) & 0.319057 & & & \\
\hline
\end{tabular}

\section{Normality Test}

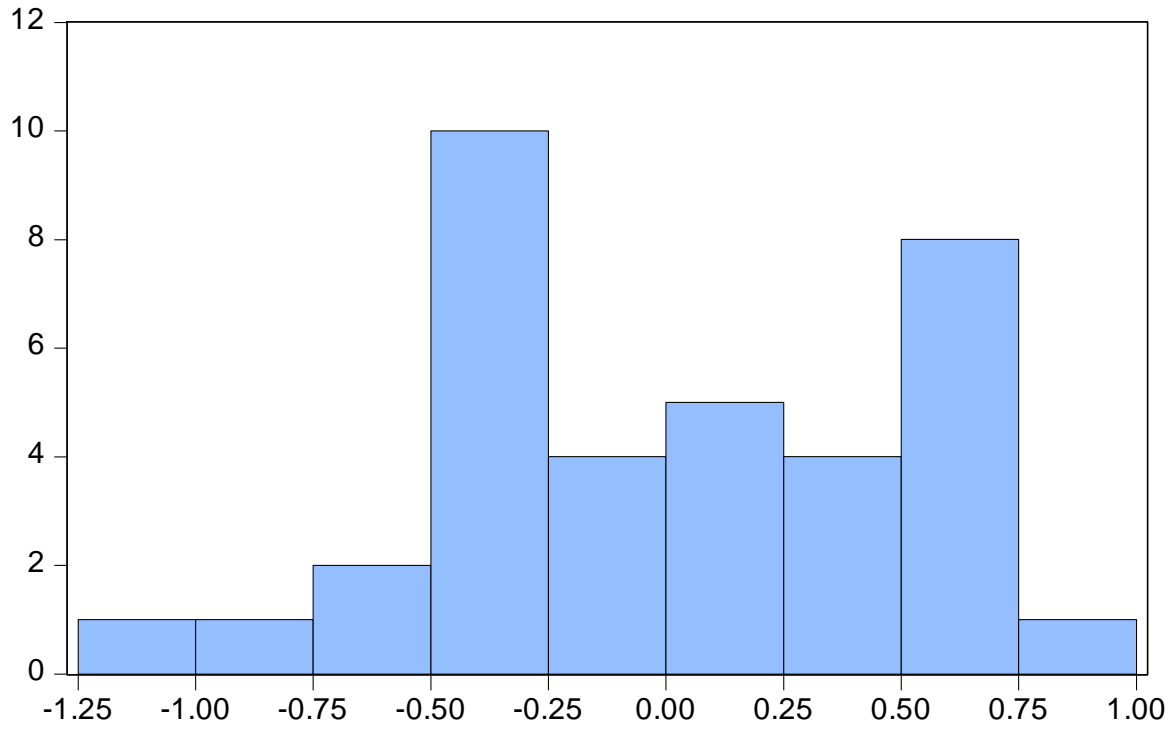

Series: Residuals

Sample 2009Q1 2017Q4

Observations 36

Mean

$2.52 \mathrm{e}-14$

Median

$-0.032107$

Maximum

0.794974

Minimum

$-1.088501$

Std. Dev.

0.504125

Skewness

$-0.063306$

Kurtosis

2.007964

Jarque-Bera

1.500248

Probability

0.472308 


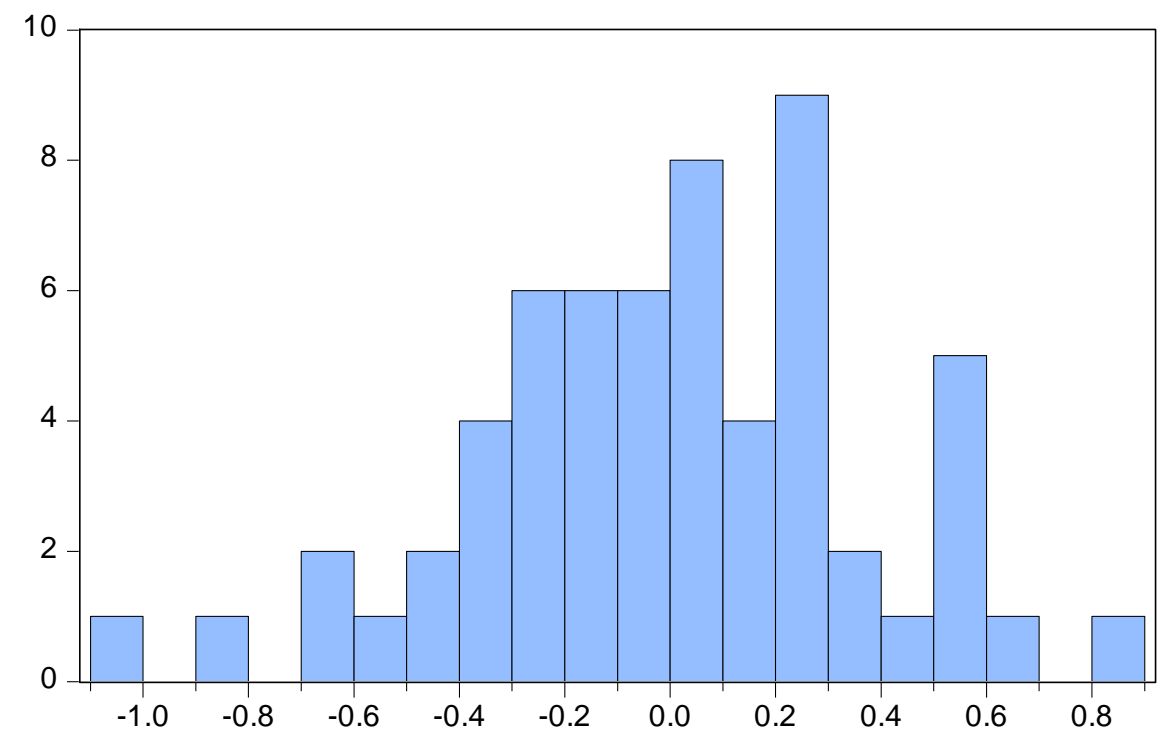

Series: Residuals Sample 2003Q1 2017Q4

Observations 60

$\begin{array}{ll}\text { Mean } & -2.21 \mathrm{e}-14 \\ \text { Median } & 0.045466 \\ \text { Maximum } & 0.806210 \\ \text { Minimum } & -1.022293 \\ \text { Std. Dev. } & 0.369980 \\ \text { Skewness } & -0.308701 \\ \text { Kurtosis } & 3.083446 \\ & \\ \text { Jarque-Bera } & 0.970370 \\ \text { Probability } & 0.615583\end{array}$

Autocorrelation Test

\begin{tabular}{|l|l|l|l|l|}
\hline Breusch-Godfrey Serial Correlation LM Test: & \\
\hline F-statistic & 1.141362 & \multicolumn{2}{|c|}{ Prob. F(2,28) } & 0.3338 \\
\hline Obs*R-squared & 2.562934 & \multicolumn{2}{|c|}{ Prob. Chi-Square(2) } & 0.2776 \\
\hline Test Equation: & & & \\
\hline Dependent Variable: RESID & & & \\
\hline Method: Least Squares & & & \\
\hline Date: 09/23/19 Time: $10: 48$ & & & \\
\hline Sample: 2009 Q3 2017Q4 & & \\
\hline Included observations: 34 & & & \\
\hline Presample missing value lagged residuals set to zero. & \\
\hline Variable & Coefficient & Std. Error & t-Statistic & Prob. \\
\hline D(D(HEALTH)) & -0.986563 & 3.553885 & -0.277601 & 0.7834 \\
\hline D(D(LEB)) & -106.8481 & 598.6812 & -0.178472 & 0.8596 \\
\hline LTRRESID & -0.000774 & 0.038926 & -0.019872 & 0.9843 \\
\hline C & -0.000114 & 0.019310 & -0.005916 & 0.9953 \\
\hline RESID(-1) & -0.247548 & 0.187852 & -1.317784 & 0.1983 \\
\hline RESID(-2) & -0.190359 & 0.188011 & -1.012489 & 0.3200 \\
\hline R-squared & 0.075380 & \multicolumn{2}{|l|}{ Mean dependent var } & 3.06 E-18 \\
\hline Adjusted R-squared & -0.089730 & S.D. dependent var & 0.107260 \\
\hline S.E. of regression & 0.111969 & Akaike info criterion & -1.382398 \\
\hline Sum squared resid & 0.351040 & Schwarz criterion & -1.113040 \\
\hline Log likelihood & 29.50076 & Hannan-Quinn criter. & -1.290539 \\
\hline F-statistic & 0.456545 & Durbin-Watson stat & 2.012536 \\
\hline Prob(F-statistic) & 0.804958 & & \\
\hline
\end{tabular}

\begin{tabular}{|l|l|l|l|}
\hline \multicolumn{3}{|l|}{ Breusch-Godfrey Serial Correlation LM Test: } & \\
\hline F-statistic & 0.892676 & Prob. F(2,52) & 0.4157 \\
\hline
\end{tabular}




\begin{tabular}{|c|c|c|c|c|}
\hline Obs*R-squared & 1.925254 & \multicolumn{2}{|c|}{ Prob. Chi-Square(2) } & 0.3819 \\
\hline \multicolumn{2}{|l|}{ Test Equation: } & & & \\
\hline \multicolumn{3}{|c|}{ Dependent Variable: RESID } & & \\
\hline \multicolumn{3}{|c|}{ Method: Least Squares } & & \\
\hline \multicolumn{3}{|c|}{ Date: 09/23/19 Time: $10: 48$} & & \\
\hline \multicolumn{3}{|c|}{ Sample: 2003Q3 2017Q4 } & & \\
\hline \multicolumn{3}{|c|}{ Included observations: 58} & & \\
\hline \multicolumn{5}{|c|}{ Presample missing value lagged residuals set to zero. } \\
\hline Variable & Coefficient & Std. Error & $\mathrm{t}$-Statistic & Prob. \\
\hline $\mathrm{D}(\mathrm{D}(\mathrm{EDUC}))$ & 0.031174 & 1.220198 & 0.025549 & 0.9797 \\
\hline $\mathrm{D}(\mathrm{D}(\mathrm{EYS}))$ & 0.327864 & 20.41465 & 0.016060 & 0.9872 \\
\hline LTRESID & 0.020549 & 0.050434 & 0.407449 & 0.6854 \\
\hline $\mathrm{C}$ & -0.000573 & 0.016566 & -0.034561 & 0.9726 \\
\hline $\operatorname{RESID}(-1)$ & -0.182628 & 0.142536 & -1.281283 & 0.2058 \\
\hline $\operatorname{RESID}(-2)$ & -0.096947 & 0.147372 & -0.657838 & 0.5135 \\
\hline R-squared & 0.033194 & \multicolumn{2}{|c|}{ Mean dependent var } & $2.75 \mathrm{E}-18$ \\
\hline Adjusted R-squared & -0.059768 & \multicolumn{2}{|c|}{ S.D. dependent var } & 0.121825 \\
\hline S.E. of regression & 0.125412 & \multicolumn{2}{|c|}{ Akaike info criterion } & -1.216722 \\
\hline Sum squared resid & 0.817869 & \multicolumn{2}{|c|}{ Schwarz criterion } & -1.003573 \\
\hline Log likelihood & 41.28495 & \multicolumn{2}{|c|}{ Hannan-Quinn criter. } & -1.133696 \\
\hline F-statistic & 0.357071 & \multicolumn{2}{|c|}{ Durbin-Watson stat } & 1.958006 \\
\hline Prob(F-statistic) & 0.875372 & & & \\
\hline
\end{tabular}

\section{Copyright Disclaimer}

Copyright for this article is retained by the author(s), with first publication rights granted to the journal.

This is an open-access article distributed under the terms and conditions of the Creative Commons Attribution license (http://creativecommons.org/licenses/by/3.0/). 